\title{
The Roles of GABA in Ischemia-Reperfusion Injury in the Central Nervous System and Peripheral Organs
}

\author{
Chaoran Chen, ${ }^{1}$ Xiang Zhou, ${ }^{1}$ Jialiang He, ${ }^{2}$ Zhenxing Xie $\mathbb{D}^{3},{ }^{3}$ Shufang Xia ${ }^{\mathbb{D}},{ }^{4}$ \\ and Guangli Lu iD ${ }^{5}$ \\ ${ }^{1}$ Institute of Nursing and Health, College of Nursing and Health, Henan University, Henan, Kaifeng, China \\ ${ }^{2}$ School of Food and Bioengineering, Henan University of Science and Technology, Luoyang, Henan, China \\ ${ }^{3}$ School of Basic Medicine, Henan University, Jinming Avenue, 475004 Henan, Kaifeng, China \\ ${ }^{4}$ Wuxi School of Medicine, Jiangnan University, Wuxi, China \\ ${ }^{5}$ Institute of Business, School of Business, Henan University, Henan, Kaifeng, China
}

Correspondence should be addressed to Zhenxing Xie; pet213@163.com, Shufang Xia; sfxia2015@163.com, and Guangli Lu; kfwangli0915@126.com

Received 11 July 2019; Revised 27 September 2019; Accepted 18 October 2019; Published 11 November 2019

Academic Editor: Reiko Matsui

Copyright (C) 2019 Chaoran Chen et al. This is an open access article distributed under the Creative Commons Attribution License, which permits unrestricted use, distribution, and reproduction in any medium, provided the original work is properly cited.

\begin{abstract}
Ischemia-reperfusion (I/R) injury is a common pathological process, which may lead to dysfunctions and failures of multiple organs. A flawless medical way of endogenous therapeutic target can illuminate accurate clinical applications. $\gamma$-Aminobutyric acid (GABA) has been known as a marker in I/R injury of the central nervous system (mainly in the brain) for a long time, and it may play a vital role in the occurrence of $I / R$ injury. It has been observed that throughout cerebral $I / R$, levels, syntheses, releases, metabolisms, receptors, and transmissions of GABA undergo complex pathological variations. Scientists have investigated the GABAergic enhancers for attenuating cerebral I/R injury; however, discussions on existing problems and mechanisms of available drugs were seldom carried out so far. Therefore, this review would summarize the process of pathological variations in the GABA system under cerebral $\mathrm{I} / \mathrm{R}$ injury and will cover corresponding probable issues and mechanisms in using GABA-related drugs to illuminate the concern about clinical illness for accurately preventing cerebral I/R injury. In addition, the study will summarize the increasing GABA signals that can prevent I/R injuries occurring in peripheral organs, and the roles of GABA were also discussed correspondingly.
\end{abstract}

\section{Introduction}

Ischemia-reperfusion is a pathological process from an initial cutoff of blood supply to an organ to the subsequent blood perfusion and the accompanying reoxygenation [1]. Frequently, I/R injury occurs in various clinical settings (e.g., thrombolytic therapy, coronary angioplasty, organ transplantation, aortic cross-clamping, or cardiopulmonary bypass) [2]. In the process, I/R is followed by some biological variations in a wide range of conditions, including vascular leakage, cell death programs (apoptosis, necrosis, and autophagy-associated cell death), autoimmunity (autoantibody and complement activation), innate and adaptive immune activation, no reflow phenomenon, and transcrip- tional reprogramming [3]. These pathological variations cause $\mathrm{I} / \mathrm{R}$ injuries of different tissues from one organ injury (e.g., acute coronary syndrome in the heart, acute kidney injury in the kidney, and intestinal I/R injury in the intestine) to multiorgan injuries (e.g., kidney and intestine injuries in trauma and resuscitation, kidney and brain injuries in circulatory arrest, and multiorgan injuries in major surgery). Multiple mechanisms are involved in the process, including free radicals, inflammation [4], the energy metabolism disorder of brain tissues, the toxicity of enhanced excitatory amino acid function, intracellular ion $\left(\mathrm{Ca}^{2+}\right)$ overload [5], the nitric oxide (NO) cytotoxic effect [6], and increased opening of the blood-brain barrier [7]. Three therapeutic strategies for $I / R$ injuries have been 
proposed, including prior to ischemia (preconditioning), during ischemia (perconditioning), and after ischemia (postconditioning) [8]. Recently, remote ischemic preconditioning has received more attentions as an optimized strategy of protecting against I/R injury in some organs with many advantages of high effectiveness, safety, noninvasiveness, easy application, and cost-effectiveness [9]. In addition, many therapeutic substances for $I / R$ injury have been developed, including endogenous substance supplements (e.g., endogenous gases: NO, carbon monoxide, and hydrogen sulfide [10]), chemical drugs (e.g., natural compounds: cannabinoids [11]; synthetic drugs: cyclosporine [12]), and stem cell therapy [13]. Due to some side effects of applying chemical drugs [14,15] and high cost of stem cell therapy [16], targeting endogenous molecules or signals may be a better choice. For instance, GABA, an abundant substance in the nervous system, is believed to be related to I/R injury.

GABA, an important neurotransmitter, had actually been synthesized in 1883 before it was found as a metabolite product in the plant and microbe [17]. Until 1950, it was found existent in mammalian brains. Hereafter, GABA was established as its neurotransmitter identity in crayfish [18]. It is now known that GABA primarily plays inhibitory effects on neuronal excitabilities of postsynaptic membrane in the central nervous system of adults [19]. GABA can also relax muscle at neuromuscular synapses [20]. However, in some cases, GABA exhibits excitatory effects (e.g., promoting contraction of enteric muscles in defecation [21] and immature CNS neurons [22]). Therefore, GABA is considered as a necessity to neural developments (e.g., neural progenitor cells and neural stem cells) and normal nervous functions. The disrupted variation of GABA levels in the nervous system may be related to numbers of nervous diseases (e.g., epilepsy [23], Parkinson's disease [24], Alzheimer's disease [25], Huntington's disease [26], psychiatric disorders [27], and stroke [28]) and other disruptions (e.g., cognitive impairment [29] and I/R injury). Besides, due to its existence in peripheral tissues and organs (pancreas, thyroid, gastrointestinal tract, lung, testis, liver, etc.) [30], GABA has also exhibited much broader physiological and pathological roles beyond the nervous system (e.g., protecting pancreas $\beta$-cell, lowering blood glucose [31], reducing inflammation [32], and alleviating I/R injury [33]). Significantly, I/R injury is a systemic pathological process which can even be involved in some nervous diseases (e.g., stroke [34]) and many peripheral organs (e.g., liver [35]). Consequently, the roles of GABA in I/R injuries of the central nervous system and peripheral organs may be a crossing topic which is receiving more and more attentions.

Over these years, with extensive researches about the physiological role of GABA and potential approaches for preventing I/R injury, the relationship between the GABA system and I/R injury is gradually revealed and some has been partly elucidated. Therefore, it is urgent to discuss emerging issues in the present data to propose topics for further investigations. However, seldom systemic reviews had been published. In this review, recent research progresses about the physiology of the GABA system and the roles of GABA in $\mathrm{I} / \mathrm{R}$ injuries of the nervous system (mainly in the brain) and peripheral organs as well as the mechanisms are summarized.

\section{A Brief of GABA Physiology}

GABA is primarily synthesized from glutamate by glutamate decarboxylase (GAD) in the body. Two GAD isoforms have been identified: GAD65 and GAD67, which derive from two cDNAs of a single separate gene [36]. Apart from existing in the nervous system, GAD is also distributed in other tissues outside the nervous system including the liver, kidney, pancreas, testis, ova, oviduct, adrenal, sympathetic ganglia, gastrointestinal tract, and circulating erythrocytes [37]. Other sources of GABA are spermine, spermidine, ornithine and putrescine which are deaminated and decarboxylated to produce GABA. GABA packed in the synaptic vesicles by vesicular GABA transporters (VGAT) is released into the synaptic cleft under triggering of $\mathrm{Ca}^{2+}$ influx to combine GABA receptors before playing physiological roles [38]. In normal physiology, GABA has difficulties to cross the blood-brain barrier [39], despite some transporters (GABA transporters (GAT)/betaine-GABA transporter) being able of transporting GABA [40].

GABA has three types of receptors, including two ionotropic receptors $\left(\mathrm{GABA}_{\mathrm{A}}\right.$ and $\mathrm{GABA}_{\mathrm{C}}$ receptors) and a metabotropic receptor $\left(\mathrm{GABA}_{\mathrm{B}}\right.$ receptor). $\mathrm{GABA}_{\mathrm{A}}$ and $\mathrm{GABA}_{\mathrm{C}}$ receptors have various pentamer combinations derived from $\alpha 1-6, \beta 1-3, \gamma 1-3, \delta, \varepsilon, \pi$, and $\theta$ subunits summarized in a review [41]. These subunits play different roles. The two ionotropic receptors mainly activate ligand-gated chloride $\left(\mathrm{Cl}^{-}\right)$ channels to produce hyperpolarization. Potassium $\left(\mathrm{K}^{+}\right)$chloride cotransporter (KCC2) pulls $\mathrm{Cl}^{-}$out of neurons [42] to keep balance of $\mathrm{Cl}^{-}$contents between inside and outside the neurons. Moreover, $\mathrm{GABA}_{\mathrm{A}}$ receptor is also the target of many substances (e.g., benzodiazepines, barbiturates, neuroactive steroids, intravenous and inhalational anesthetics, and ethanol [43]), in which benzodiazepines are well known for their applications as positive allosteric modulators of $\mathrm{GABA}_{\mathrm{A}}$ receptor [44]. $\mathrm{GABA}_{\mathrm{B}}$ receptor has two subunits (B1 and $\mathrm{B} 2$ ) and is a $G$ protein-coupled receptor, mediating inhibitory effects by activating voltage-gated $\mathrm{Ca}^{2+}$ channels, $\mathrm{K}^{+}$channels, and adenylyl cyclase to induce cell hyperpolarization and inhibit neurotransmitter releases [45].

After producing biological effects, most GABA is reabsorbed from synaptic cleft and reused by GAT. GAT has four types: GAT1, GAT2, GAT3, and betaine-GABA transporter [46]. GAT1 and GAT3 are the major types in the brain, regulating the balance of GABA [47]. The GAT1 is especially important in neurons and can also inversely transport GABA out of neurons with uncertain mechanisms [48]. GAT3 is mostly distributed in glial cells [49]. GABA entry into cells is metabolized by two catabolic enzymes: GABA transaminase and succinic semialdehyde dehydrogenase (SSADH). The final metabolic product of GABA, succinic acid, enters into the tricarboxylic acid cycle for energetic supplements [50].

\section{The Role of GABA in Cerebral $I / R$ Injury in Adult}

3.1. Variations of GABA Levels, Synthesis, and Metabolism during Cerebral I/R Injury. It is well known that cerebral ischemia injury can cause high mortality and disability [51]. 
Although the reperfusion is used to restore brain blood supplement, it can also induce further injuries involving a complex pathological progress (I/R injury) [52]. Many mechanisms have been proposed to explain the progress, including toxicity of high glutamate activity, $\mathrm{Ca}^{2+}$ overload, oxidative stress, inflammation and apoptosis, inflammation, breakdown of the blood-brain barrier, cerebral infarction, and edema [52-54]. The imbalance including the decreased transmission of GABA signal and the increased excretion of excitatory amino acid (glutamic acid) in $I / R$ [55] indicated that GABA may play special roles in the process of $I / R$ injury. Enhancing GABA actions by different enhancers of GABA transmission can partly restore the balance of GABA and glutamate transmissions, pointing out a potential preventive strategy for cerebral I/R injury. Even an enhanced GABA signal pathway can inhibit glutamate release induced by ischemia, such as treatment with GABA receptor agonists [56], promoting normalization of the two neurotransmitter pathways.

First, accumulating data had shown that GABA levels and the function status of its metabolism are affected differently in different periods of cerebral I/R injury, reflecting that the GABA system can be an important index of cerebral I/R injury and also monitor the restoration of cerebral I/R injury. The most prominent feature in these phenomena is the rise of extracellular GABA levels in most cerebral I/R injuries, while in transient cerebral ischemia, GABA levels return to the nor$\mathrm{mal}$ at the start of reperfusion, or in repeated ischemia, it decreases to the undetected level [57]. Recent studies showed that in animals $[58,59]$ and humans [60] suffering ischemia attacks, GABA contents in the cerebral hemisphere actually declined. Although the efflux transport of GABA out of the brain via the blood-brain barrier increased in $I / R$ injury [61], reduced GABA contents may mainly result from the variations of GABA synthesis, release, and metabolism. In the early stage of ischemia, GABA release and the inhibition of its metabolism may mainly be responsible for increased GABA levels. Allen et al. found that GABA releasing was induced sequentially by the exocytosis due to the entering of extracellular $\mathrm{Ca}^{2+}$ into neurons during the anoxic depolarization, and then, reversed uptake of GABA by GAT1 occurred after the anoxic depolarization [48]. However, upregulated GAT1 expressions under ischemic conditions after a long time started the removal of GABA from the synaptic cleft [62], reducing GABA metabolism. In the aspect of GABA synthesis, the variation of GAD after cerebral I/R has a striking similarity. Moreover, increased expressions of GAD in a short time after I/R (e.g., large aspiny neurons [63]) can produce more GABA and provide the basis for GABA release and reversed uptake of GABA by GAT1 in neurons to increase the survival. After that, the loss of GABAergic neurons [64] and the decrease of GAD protein expression [65] occurred (e.g., in substantia nigra of chronic ischemia rats). At this point, although increased protein expression of GAD (GAD67) may compensate the neuron injury induced by hypoxia-ischemia, elevated GAD expression is also associated with cell death [66], and the compensation is even weaker in the immature brain compared with the mature brain. Another study showed that truncated cleavage product (tVGAD) from VGAD by calpain following focal ischemia had the lower ability in the GABA synthesispackaging coupled with VGAT, leading to reduced GABA transmission despite its increased activity compared with that of VGAD in the focal cerebral ischemic rat brain [67]. Further, the decreased mRNA level of the VGAT [68] after $\mathrm{I} / \mathrm{R}$ indicated faster eliminations and slower packages of GABA. However, the protein levels of VGAT in substantia nigra pars reticulate [65] and other brain regions [69] were stable after ischemia by using immunohistochemistry. It may be due to the rapid formation of a stable truncated cleavage product (tVGAT) from VGAT under ischemia by calpain which cannot be discriminated by immunohistochemistry and may further decrease GABA release after a long time [70]. The reason may be that tVGAT is redistributed out of synaptosomes with an unclear mechanism, probably explaining reduced GABA release with more production and redistribution of tVGAD in ischemia [67]. In addition, the protein levels of SSADH and SSAR were reduced in some regions after ischemia [71], indicating that GABA metabolism was disturbed, and due to the downregulated SSADH level, the less supplement of GABA shunt to produce adenosine triphosphate (ATP) in pyruvate dehydrogenase into the tricarboxylic acid cycle aggravated the neuron damages.

3.2. Expressions, Binding Abilities, and Signal Transmissions of GABA Receptors during Cerebral I/R. Apart from the normal GABA level in the brain necessary for maintaining neural functions in the cerebral I/R process, GABA receptors and GABA signal transmissions are also very vital. An interesting study had well proved the view of point that only blocking GABA synthesis is not enough to alter neuron functions. A study [72] showed that reduced GABA production by a GAD inhibitor did not alter dendrite growth in vitro. So, GABA receptors and their transmissions may be involved in neural I/R injury. Thus far, data about variations of GABA receptors showed the characteristic of time dependence resulting from I/R injury of the mature neuron. A previous study had demonstrated that the level of $\mathrm{GABA}_{\mathrm{A}}$ receptor in the hippocampus and cerebral cortex was downregulated within $30 \mathrm{~min}$ after I/R [73]. In mechanism, the reduced density of $\mathrm{GABA}_{\mathrm{A}}$ receptor probably accounted for this event. It can result from the internalization of $\mathrm{GABA}_{\mathrm{A}}$ receptor mediated by dephosphorylation of its $\beta 3$ subunit (serine 408/409) [74], which occurred under increased recycling of $\mathrm{GABA}_{\mathrm{A}}$ receptor by huntingtin-associated protein 1 [75] and decreased $\mathrm{GABA}_{\mathrm{A}}$ receptor clustering by downregulating a protein (gephyrin) responsible for the transport and synaptic anchoring of $\mathrm{GABA}_{\mathrm{A}}$ receptor after oxygen-glucose deprivation [76]. Differently reduced $\mathrm{GABA}_{\mathrm{A}}$ receptor density was also demonstrated in the optic lobe of an embryonic chicken [77]. Meanwhile, the mRNA levels of $\mathrm{GABA}_{\mathrm{A}}$ receptor subunits $(\alpha 1$ and $\alpha 2)$ in the hippocampus and dentate gyrus were also downregulated in another study [78]. Besides, at $48 \mathrm{~h}$ after transient global ischemia, there were different variations of $\mathrm{GABA}_{\mathrm{A}}$ receptor subunit $(\alpha 1, \beta 2$, and $\gamma 2)$ mRNA in cerebral cortexes (no change) and caudate putamens (upregulated both subunits) in the rat ischemia model [79], indicating different injuries in different brain regions in the 
same time. However, despite the confirmed upregulated mRNA levels of $\mathrm{GABA}_{\mathrm{A}}$ receptor $\alpha 1$ and $\alpha 2$ subunits [80], protein contents of the $\alpha 1$ subunit in rats with brain ischemia induced by the manmade thrombus decreased at 7 days after I/R [81]. In other cases, subunits (e.g., $\alpha 1$ ) of $\mathrm{GABA}_{\mathrm{A}}$ receptors in the perilesional cortex were highly expressed, which may induce functional reorganization (increase in dendritic-like structures [82]) or other dysfunctions of the nervous system (e.g., epileptogenesis [83]) in cerebral I/R injury. In addition, although the mRNAs of $\mathrm{GABA}_{\mathrm{B}}$ receptor subunits (B1 and $\mathrm{B} 2$ ) were detected coexisting with parvalbumin in gerbil hippocampus neurons at 4 days after transient global ischemia [84], these neurons surviving the ischemia insult were just a few. In vitro, a brief episode of oxygen and glucose deprivation can decrease $\mathrm{GABA}_{\mathrm{B}}$ receptor contents in the cell surface through activating endoplasmic reticulum stress [85]. Therefore, the fluctuating process of GABA receptor expressions hinted the decline of neuron functions or even death in cerebral I/R injury. In contrast, GABA receptors in young individuals were more vulnerable and caused functional compliments. For instance, the mRNA levels of $\mathrm{GABA}_{\mathrm{A}}$ receptor $\alpha 1, \beta 2$, and $\gamma 2$ subunits significantly decreased in the cerebral cortex and caudate putamen in young ischemia rats [79]. These variations in neonatal individuals can directly induce seizure occurrence [86].

On the other hand, the functional status of GABA receptors is also responsible for normal GABA signal transmission. It had been demonstrated that the binding abilities of GABA receptors with ligands declined after ischemia and the binding activity is often characterized by the binding value of special agonists with them. For instance, muscimol, a GABA receptor agonist, had a lower binding value in the ischemic cortical penumbra after transient focal cerebral ischemia I/R [87]. Even after transient oligemia, a significant reduction of $\mathrm{GABA}_{\mathrm{A}}$ receptor binding values can last for a long time [88]. Conversely, $\mathrm{GABA}_{\mathrm{A}}$ receptor in surviving neurons of the gerbil hippocampus against I/R had upregulated binding abilities with muscimol according to a research [89]. However, the tolerance of neurons was just limited in a certain period (within $48 \mathrm{~h}$ after cerebral I/R).

Moreover, the intracellular signal transmission of GABA receptors also disrupts. Inhibitory postsynaptic potentials induced by GABA had disappeared ex vivo [90] or weakened in vitro [91] in the short term after ischemia. GABA signal transmission also declined with reduced chloride ion influx in vivo [91], in vitro [92], and ex vivo [90]. Downregulation of KCC2 may be responsible for the results [93], which are unable of restoring $\mathrm{Cl}^{-}$gradient on both sides of the neuron membrane. In a research about long-term injuries after ischemia, the dysfunction of GABA signal transmission was remarkable, despite the normal presynaptic neurons which had survived the I/R injury releasing a normal amount of GABA [94]. This result indicated that GABA transmission after GABA receptors was more fragile. On the other hand, high-resistant neurons still exhibited the normal response ability of the GABA receptor. Zhan et al. found that miniature inhibitory postsynaptic currents and GABA-evoked currents in high-resistant CA1 interneurons after transient forebrain ischemia did not decrease [95], which might delay the I/R injury. Liang et al. further proved that the enhancement of GABA synaptic transmission in CA1 neurons following forebrain ischemia was attributed to the postsynaptic signal dysfunction rather than disrupted GABA releasing in the presynaptic membrane [96]. The research had proved that adenosine A1 receptor activation was a potential reason for the phenomenon. Other factors after ischemia had been proposed accounting for the dysfunction of postsynaptic GABA transmission in a comprehensive review [97], including increase in intracellular chloride ion, accumulation of some signal substances (e.g., $\mathrm{Ca}^{2+}$ and eicosanoids), production of reactive oxygen species, and reduction of ATP. In addition, the degradation of tumor suppressor phosphatase and tensin homolog after ischemia had double effects according to a recent research [98]. The molecule can enhance GABA-evoked current to protect neural functions by increasing the expression of $\mathrm{GABA}_{\mathrm{A}}$ receptor $\gamma^{2}$ subunit on the one hand and has the converse action of damaging astrocyte functions on the other hand.

3.3. The Protective Effects of GABA and Its Enhancers on Cerebral I/R Injury. In view of the importance of GABA in cerebral I/R injury and the difficulty of GABA crossing the blood-brain barrier, some GABAergic drugs had been used for attenuating I/R injury in clinical and animal tests. Early in 2001, Schwartz-Bloom and Sah had reviewed some GABAergic drugs used in I/R animals and few human subjects [97], including GABA agonists (e.g., muscimol, thip, and baclofen), GABA modulators (e.g., benzodiazepines), GABA uptake inhibitors (e.g., tiagabine), and GABA metabolism inhibitors ( $\gamma$-vinyl GABA). However, due to the narrow therapeutic window, only short-term protective effects (about 1 month) against cerebral I/R injury were demonstrated in most researches. Moreover, adverse effects of some drugs aggravating neuronal deaths were frustrating. The discussion of further mechanisms was still limited. Most importantly, selective applications of these drugs and clinical investigations were not discussed due to the shortage of data. In recent years, much broader and deeper studies were illuminating to develop preventive and therapeutic strategies for cerebral I/R through targeting the GABA signal pathway. In this section, an updated review from several aspects of new progresses was made.

\subsubsection{The Clinical Effects of GABA on Cerebral I/R Injury. For} a long time, barbiturates had clinically been used to control the intracranial hypertension in transient ischemia events in the operating room; some potential side effects (having a depressant effect on the cardiovascular and respiratory systems) might affect the applications (e.g., needing intensive care) [99]. Meanwhile, another system review [100] summarized that GABA receptor agonists (e.g., chlormethiazole) had better effects on patients with acute ischemic (within 12 hours) or hemorrhagic stroke. Some adverse events (e.g., somnolence and rhinitis) also occurred. Recently, the longterm intrathecal treatment of baclofen can improve the functional independence in the traumatic brain injury and stroke groups [101]. However, adjustments of doses were complex and needed further investigations. In addition, GABA 
enhancer treatments, such as rac-hopantenic acid (pantogam activ) [102, 103] and adaptol [104], remarkably improved psychopathological, psychometric, and detailed somatic functions (e.g., cognitive functions, but also emotional state) with reduced adverse events (e.g., drowsiness and headaches) in patients with chronic cerebral ischemia. Therefore, developing new drugs of GABA enhancers with less adverse effects may be the next focus of clinical studies.

\subsubsection{The Relationship between Doses and Effects May Be an} Important Reference Point. Effective doses are needed in using GABA enhancers for cerebral I/R injury. For instance, some enhancers of GABA actions (e.g., topiramate and $\gamma$-vinyl GABA) cannot prevent focal I/R injury induced by the occluding right middle cerebral artery in functional or histological measures at high concentrations of the two drugs $(100 \mathrm{mg} / \mathrm{kg}$ and $1000 \mathrm{mg} / \mathrm{kg}$, respectively) whether in preconditioning or following ischemia [105]. A later study showed that $\gamma$-vinyl GABA (30-300 $\mu \mathrm{mol} / \mathrm{L})$ exhibited "U-shaped" effects of antagonizing LDH and glutamate releases induced by hypoxiaglucose deprivation/reoxygenation in vitro [106]. In addition, cotreatment may produce better effect despite lower doses. Cotreatments of $\gamma$-vinyl GABA $(30 \mathrm{mg} / \mathrm{kg})$ with purinergic (P2X) receptor antagonists intraperitoneally (i.p.) can prevent neuronal cell death of the gerbil hippocampus at $24 \mathrm{~h}$ after I/R [107], and it alone has no effects. Diazepam has also "Ushaped" effects both in vivo $(0.5-10 \mu \mathrm{mol} / \mathrm{L})$ [108] and in vitro $(0.5-5 \mu \mathrm{mol} / \mathrm{L})$ [109], though its effect was involved in hypothermic neuroprotection [110]. Whether the mechanism is related to the status of the GABA signal or through other pathways may be the next focus.

3.3.3. More Mechanisms Based on or beyond GABA Signal Transmission. With the broader researches of using GABAergic drugs preventing cerebral I/R injury, some strategies are emerging and may produce better effects (e.g., coadministrations of $\mathrm{GABA}_{\mathrm{A}}$ and $\mathrm{GABA}_{\mathrm{B}}$ receptors having better effects than given alone in the in vitro ischemia model [111]) and less adverse effects (e.g., special activations of GABA subunits: $\beta$, $\alpha 1$, and $\gamma$; coadministrations of etomidate and propofol; and coadministrations of zolpidem and diazepam [112]).

Moreover, multiple mechanisms had been presented in exploring the effects of different GABAergic enhancers in cerebral I/R (Table 1), including improved expressions of GABA receptors (or subunits); increased NO synthase and postsynaptic density 95 (PSD95) interaction; activated $\alpha 2-\delta$ subunit of the voltage-dependent $\mathrm{Ca}^{2+}$ channel and $\mathrm{Ca}^{2+} /-$ calmodulin-dependent protein kinase II; upregulated B-cell lymphoma-2 (Bcl-2) expressions; decreased Bcl-2-like protein $4(\mathrm{Bax}) / \mathrm{Bcl}-2$ ratio; downregulated expressions of procaspase- 3 and caspase-3 through glutamate receptor 6 (GluR6)/PSD95/mixed lineage kinase 3 (NLK3)/c-Jun Nterminal kinase 3 (JNK3) and protein kinase $M$ zeta $(\mathrm{PKM} \zeta) / \mathrm{KCC} 2$; reduced glutamate and lactate dehydrogenase $(\mathrm{LDH})$ levels; inhibited N-methyl-d-aspartic acid (NMDA) receptor/Src-mediated signal; suppressed autophagy by activating protein kinase B (Akt), glycogen synthase kinase-3 beta (GSK-3 $\beta$ ), and extracellular regulated protein kinases (ERK) and neutrophil-directed migration in a phos- phoinositide 3-kinase- (PI3K-) dependent manner; attenuated oxidative stress; decreased intracellular $\mathrm{Ca}^{2+}$ contents; and restored contents of brain-derived neurotrophic factor (BDNF), vascular endothelial growth factor (VEGF), tyrosine kinase B (TrkB), neural cell adhesion molecule (NCAM), and $G$ protein-activated inwardly rectifying potassium (GIRK, Kir3). Among them, most played the roles which may be related to improved GABA transmission. However, individual drugs played the protective effect through some pathways which were irrelated to GABA signals. For instance, diazepam acted on the peripheral benzodiazepine receptor in the outer mitochondrial membrane [108]. Therefore, more potential mechanisms related to GABA signal or other effects in or outside the ischemia regions needed further investigations, and systemic classifications of different GABA enhancers are necessary in the long run.

\subsection{The Protective Effect of Preconditioned and Delayed} Treatments with GABA Transmission Inhibitors on Adult Cerebral I/R Injury. However, in some circumstances, preconditioned and delayed treatments with GABA transmission inhibitors can produce protective effects on adult cerebral I/R injury according to limited studies. In fact, an early study had already some kind of hint. A benzodiazepine receptor partial agonist (PNU-101017) intriguingly exhibited the better effect of preventing hippocampal neuronal degeneration in $\mathrm{I} / \mathrm{R}$ injury than a full benzodiazepine receptor agonist [129] in preconditioning. The difference was more obvious when the two drugs were given after ischemia. The result was probably due to GABA receptor overactivations after I/R, triggering the outward of bicarbonate over the inward of $\mathrm{Cl}^{-}$and a further depolarization. Recently, some reports further confirmed the effect. First, the treatment with $\mathrm{GABA}_{\mathrm{A}}$ receptor antagonist (bicuculline) at 1-2 days before oxygen-glucose deprivation made the cultured cortical neurons more tolerant to the insult [130]. The mechanism was related to calmodulin-dependent phosphorylations of ERK1/2 and cAMP-response element binding protein (CREB). Interestingly, alike results were also obtained in vivo. In a study, in contrast to attenuating $\mathrm{I} / \mathrm{R}$ injury by activating GABA transmissions in adults, the treatment with a $\mathrm{GABA}_{\mathrm{A}}$ receptor $\alpha 5$ subunit inverse agonist $(\mathrm{L}-655,708)$ at a low dose of $1.5 \mathrm{mg}$ by subcutaneous implantation at 1 week after the focal ischemia induced by cortical microinjection of endothelin-1 can significantly restore motor skills of ischemia stroke rats by inhibiting GABA signal [131]. Recently, L-655,708 treatment $(1,5 \mathrm{mg} / \mathrm{kg})$ only after 3 days after middle cerebral artery occlusion can trigger neurogenesis [132]. It hinted that the targeted inhibition of special GABA receptor subunits may be the key. In another research, Alia et al. found that hampering $\mathrm{GABA}_{\mathrm{A}}$ transmission after photothrombotic ischemia by a benzodiazepine inverse agonist (DMCM: methyl-6,7-dimethoxy-4-ethyl-beta-carboline-3carboxylate, i.p., $1.5 \mathrm{mg} / \mathrm{kg}$ ) can significantly improve motor function [133]. The effect of DMCM may remodel GABAergic inhibitory networks controlling motor function. Although limited reports were presented, more mechanisms about status of GABA receptors and its signals during the period of $\mathrm{I} / \mathrm{R}$ injury may be responsible for the results. 


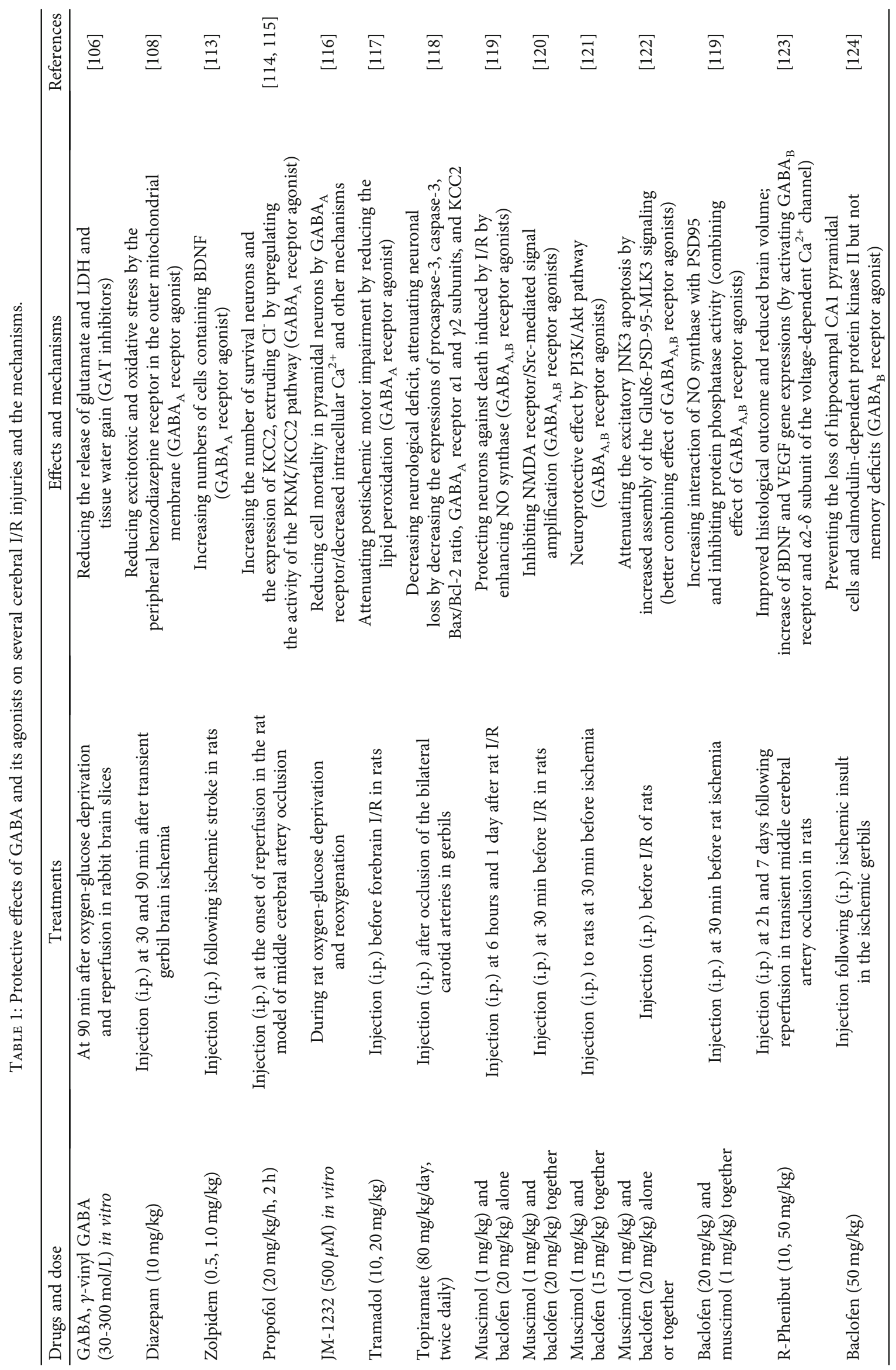




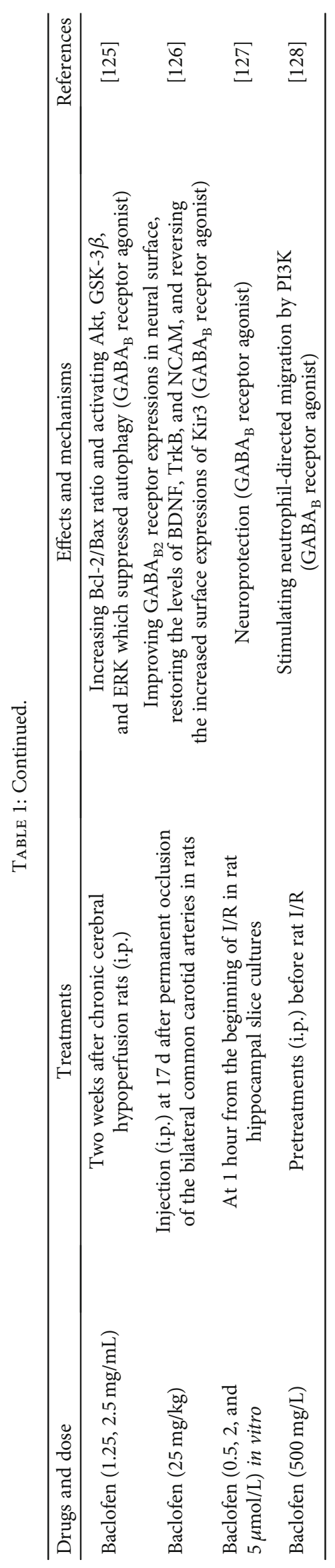


Preconditioned and delayed treatments may also be the key of the effect. Therefore, more accurate effects concerning GABAergic inhibitory drugs need further investigations.

\section{The Role of GABA in Cerebral I/R Injury in Neonate}

As stated above, GABA exhibits excitatory effects in the immature nervous system compared with inhibitory effects in the mature nervous system. Therefore, its effect on cerebral $\mathrm{I} / \mathrm{R}$ injury of neonate was specially discussed in this section. Thus far, limited studies showed that GABA transmission inhibitors played the protective effects on neonatal cerebral I/R injury. The effects may be due to increased GABA levels and the losses of GABA receptors (subunits) or its pathway expressions $[86,134,135]$ occurring in immature I/R injury, hinting possible overactions of the GABA transmission pathways. This point can be demonstrated in a study that a $\mathrm{GABA}_{\mathrm{A}}$ receptor antagonist (bicuculline) can further enlarge the intracellular $\mathrm{Ca}^{2+}$ accumulation under reduction in $\mathrm{Cl}^{-}$gradient across the membrane induced by oxygen-glucose deprivation in neonatal rat neocortex [136]. Therefore, activating $\mathrm{GABA}_{\mathrm{A}}$ receptor may aggregate the $\mathrm{I} / \mathrm{R}$ injury in the neocortex of neonatal rats. Moreover, treatments with two $\mathrm{GABA}_{\mathrm{B}}$ receptor antagonists (CGP 35348 and CGP 55845) can remarkably improve the motor function and inflammatory response of 10-day-old rats subjected to the hypoxia-ischemia stimulation [137-139]. In another study [140], a GABA receptor agonist (topiramate) generated more damage to the brain and the cognitive ability injury in the hypoxic-ischemic brain of neonatal rats (over 7-day age), except for protective effect on hypoxicischemic brain injury in rats $(1,4$-day age). However, the mechanism of the latter effect was not further explored.

\section{The Role of GABA in Spinal Cord I/R Injury}

Spine cord ischemia is a rare event and difficult to diagnose for its varying degrees of injury. Its clinical manifestations include anterior spinal artery syndrome, posterior spinal artery syndrome, and spinal transient ischemic attacks (e.g., transverse medullary infarction, central spinal infarct, infarction at the level of conus medullaris, and sulcocommissural syndrome) [141]. GABA within the spinal cord should have equal significance as in the brain. However, seldom studies about the role of GABA in spinal cord I/R injury were presented. Limited studies showed that the GABA level significantly decreased [142, 143] and spontaneous inhibitory postsynaptic currents induced by GABA increased [144] after spinal cord I/R, hinting the overactivation of GABA signal transmission. However, inconsistent results according to the present data showed that both GABA agonists and antagonists can restore spinal cord I/R injury. For instance, the former (intraperitoneal treatment with vigabatrin [145] and intrathecal treatments with baclofen and nipecotic acid [146]) can restore histopathologic injury, spasticity, and rigidity in rats after transient spinal cord ischemia. The latter (i.v. bicuculline and semicarbazide [147]) mainly restored reflex potentials after spinal cord ischemia in cats. Thus, the complex mechanism of the role in spinal cord I/R injury exists and needs further distinguishing.

\section{Roles of GABA in I/R Injuries of Other Organs outside of the Nervous System}

6.1. GABA and Gastric I/R Injury. Gastric ischemiareperfusion is a common clinical problem associated with various physiopathological stress conditions such as surgery, hemorrhagic shock, peptic ulcer bleeding, vascular rupture, and ischemia gastrointestinal disease, which may cause the damage of the gastric mucosa [148]. In these processes, the dysfunction occurring in the neuroendocrine system can induce increased catecholamine levels, vasoconstriction, decreased cardiac output, reduced blood volume, and the release of proinflammatory factors [149], which promote flow of blood into the heart, brain, and muscles from the gastrointestinal tract and skin [150]. So, the central nervous system may play a vital role in gastric I/R injury. Nowadays, fastigial nucleus (FN), hypothalamic paraventricular nucleus (PVN) [151, 152], and lateral hypothalamic area (LHA) [153] are thought as major regions regulating gastric activity and gastric mucosal injury in gastric I/R injury. The GABA system, abundant in the central nervous system, was proved playing a vital role in attenuating gastric I/R injury. Zhu et al. [154] found that microinjecting glutamate into the interpositus nucleus (IN) of the cerebel can attenuate gastric I/R injury, decrease discharge frequency and intensity of greater splanchnic nerve (GSN), and improve blood flow, apoptosis, and proliferation of rat gastric mucosa. The effect can be reversed by the pretreatments of microinjecting 3mercaptopropionic acid (GAD inhibitor) into IN or bicuculline into LHA. The result suggested that GABAergic neuron in IN acted on its receptors in the lateral hypothalamic area and subsequently inhibited the activity of the GSN innervating stomach. Its dysfunction was considered as an important promoter of gastric I/R injury progression. Also, GABAergic neurons in FN of the cerebellar also participated in attenuating gastric I/R injury through the cerebellar-hypothalamic circuit [155]. Another study [156] further proved that high levels of $\mathrm{GABA}_{\mathrm{A}}$ receptor in the LHA of rats could be responsible for significantly alleviated gastric I/R injury by the overexpression of the receptor induced by adenoviral vector. Reduced norepinephrine and angiotensin II levels in plasma and peripheral GSN activity marked multiple ways of GABA preventing against gastric $I / R$ injury in the study. A recent investigation [157] showed that the $\mathrm{GABA}_{\mathrm{B}}$ receptor in the LHA was involved in the protective effects on the gastric I/R injury caused by clamping the celiac artery. The administration of $\mathrm{GABA}_{\mathrm{B}}$ receptor agonist (baclofen) can significantly attenuate gastric I/R injury. Interestingly, significantly reduced oxidative stress indexes (e.g., nicotinamide adenine dinucleotide phosphate-oxidase (NOX2, NOX4)) and attenuated inflammation (IL-1 $\beta$ ) in the gastric mucosa by baclofen treatment were observed in model rats. Although the pathway of baclofen attenuating gastric I/R injury was probably through decreasing expressions of NOX2/NOX4, the neuroendocrine effect mediated by neurotransmitter calcitonin gene-related peptide also played the important role 
because the neurotransmitter is released by neurons innervating the stomach from the dorsal root ganglion under the injection of baclofen into the LHA. Therefore, GABA or its agonists may have the prospect of curing gastric I/R injury. However, the direct effect of GABA in gastric $I / R$ is still unclear.

6.2. $G A B A$ and Intestinal $I / R$ Injury. Intestinal ischemiareperfusion (IIR) injury occurs in numerous clinical events following intestinal ischemia, such as superior mesenteric artery occlusion, hemorrhagic shock, intestinal and liver transplantation $[158,159]$, neonatal necrotizing enterocolitis [160], volvulus [161], trauma [162], and cardiopulmonary disease [163]. IIR injury can induce the damage and dysfunction of multiple organs [164]. Although improved treatments were recently applied to clinical tests, the morbidity and mortality still remained high [165]. Studies about the effect of GABA on IIR injury had just begun. A recent study [166] showed that IIR resulted in a significant decrease of intestinal innate immunity indexes (immunoglobulin A, alpha-defensin-5, and antioxidative enzyme) in Peyer's patch cells of the rat small intestine, and GABA pretreatments (oral administration, $30 \mathrm{mg} / \mathrm{kg}$ ) significantly produced the protective effects on IIR injury in which mRNA levels of R alphadefensin-5 and superoxide dismutase 1, 3 together with immunoglobulin A levels were increased in vitro. In addition, GABA receptor activations in rat focal cerebral I/R injury seem to affect intestinal flora [167], suggesting that indirect effect of GABA on IIR may exist. Therefore, GABA's indirect effect and clinical data about applying GABA or its agonists to prevent or cure IIR injury should be focused in the future.

6.3. $G A B A$ and Renal $I / R$ Injury. I/R injury is primarily responsible for acute kidney injury, which can cause high mortality and morbidity and elevated cost of treatment $[168,169]$. Renal I/R injury is the restoration of blood reperfusion after the blocking of renal blood flow, which often occurs in surgeries of vascular and cardiac, trauma, and kidney transplantation $[170,171]$. GABA may play important roles in renal physiology and pathology [172]. For instance, GABA has been reported to regulate blood pressure by increasing excretion of water and sodium ion $\left(\mathrm{Na}^{+}\right)$in the kidney ex vitro [173]. Recent studies showed that GABA can attenuate renal I/R injury from two pathways of the central nervous system and the peripheral nervous system. Kobuchi et al. found that intravenous injection of GABA (10 and $50 \mathrm{mmol} / \mathrm{kg}$ ) can dose-dependently suppress the elevated activity of renal sympathetic neuron and the venous norepinephrine overflow in the rat renal I/R model [33]. Selective treatment using $\mathrm{GABA}_{\mathrm{B}}$ receptor antagonist (CGP52432) can reverse the protective effect of GABA on renal $\mathrm{I} / \mathrm{R}$ injury, hinting that $\mathrm{GABA}_{\mathrm{B}}$ receptor is the targets of GABA action. Then, $\mathrm{GABA}_{\mathrm{A}}$ receptor antagonist picrotoxin had been found aggravating the acute kidney injury induced by $\mathrm{I} / \mathrm{R}$ in investigating the mechanism of sodium valproate (reducing GABA degradation) protecting against renal I/R injury [174], suggesting that $\mathrm{GABA}_{\mathrm{A}}$ receptor directly plays the protective effect of GABA on renal I/R injury compared with the little, no, or opposite effect of
$\mathrm{GABA}_{\mathrm{B}}$ receptor in the condition of GABA shortage. But a recent study [175] showed that $\mathrm{GABA}_{\mathrm{A}}$ receptor antagonist (bicuculline) treatment by the intracerebroventricular administration was unable to prevent the preventive effect of GABA on renal I/R injury. Conversely, renal I/R injury could be prevented by $\mathrm{GABA}_{\mathrm{B}}$ receptor agonist (baclofen), indicating that activated $\mathrm{GABA}_{\mathrm{B}}$ receptor in the central nervous system was responsible for the protective effect. In addition, the effect of GABA on renal I/R injury exhibited gender-related difference. GABA treatment can attenuate pathological renal parameters (blood creatinine and urea nitrogen, kidney weight, and renal level of malondialdehyde) in female rats rather than male rats [176]. However, it was intriguing that GABA was unable to protect renal I/R injury in ovariectomized rats whether estradiol was administrated or not [177]. The result suggested that variations of the internal environment in different physiological states may interrupt the effect of GABA on renal I/R injury. Therefore, more complex internal environments need considerations.

6.4. GABA and Hepatic I/R Injury. Hepatic I/R injury is a systemic pathological process which induces not only hepatic function and irreversible injury but also cascade of dysfunctions of other organs [178]. Hepatic I/R injury occurs in some clinical scenarios, including liver resection (e.g., the Pringle maneuver and the hepatic vascular exclusion in liver surgery), liver transplantation, and trauma [179-181]. Two types of hepatic I/R injuries have been proposed. The preservation and storage of the liver before transplantation can cause cold I/R injury [182]. Liver surgery, trauma, setting of transplantation, etc. can induce warm I/R injury due to transient blockage of blood flow [183]. A lot of mechanisms are involved in hepatic I/R injury, including oxidative stress, inflammation, respiratory chain dysfunction of mitochondria, Kupffer cell activation, upregulated vascular cell adhesion molecule, and polymorphonuclear neutrophil injury [184]. Some substances with antioxidative and antiinflammatory activities had demonstrated protective effects against hepatic I/R injury [178]. Recently, novel targets for attenuating hepatic I/R injury were also proposed (e.g., peroxisome proliferator-activated receptor gamma and several noncoding RNAs) [185]. However, the mechanism remained unclear. Present data showed that GABA was associated with hepatic I/R injury. First, it had shown that GABA may play an important role in monitoring hepatic I/R injury. According to a clinical study about 18 patients, GABA levels in the grafts for liver transplantation immediately after the reperfusion with an isotonic solution for 48 hours were remarkably decreased and then stabilized at baseline values [186]. Thus, GABA can be an index predicting the changing process of a normal functioning liver graft and may participate in protecting hepatic I/R injury. Further studies showed that GABA agonists can attenuate hepatic I/R injury. An animal research showed that pretreatment of donor rats in vivo by $\mathrm{GABA}_{\mathrm{A}}$ receptor agonist (muscimol) before the liver graft surgery significantly reduced the liver cold ischemia/warm reperfusion injury and oxidative stress after the orthotopic liver transplantation [187]. At the end of 6 hours, after the orthotopic liver transplantation with the same treatment on recipient 
TABLe 2: Protective effects of GABA receptor enhancers on myocardial I/R injuries and the potential mechanisms.

\begin{tabular}{|c|c|c|c|c|}
\hline Species & I/R model & Drugs and dose & Effects and mechanisms & References \\
\hline $\begin{array}{l}\text { Wistar rats: in vivo } \\
\text { and in vitro }\end{array}$ & $\begin{array}{l}\text { Ischemic } 20 \mathrm{~min} \text {, } \\
\text { reperfusion } 5 \mathrm{~min}\end{array}$ & $\begin{array}{l}\text { Phenazepam preconditioning } \\
1 \mathrm{mg} / \mathrm{kg}\end{array}$ & $\begin{array}{l}\text { Anticonvulsant and } \\
\text { antiarrhythmic effect by } \\
\text { central nervous system }\end{array}$ & [191] \\
\hline $\begin{array}{l}\text { Chick cardiomyocyte } \\
\text { in vitro }\end{array}$ & $\begin{array}{l}\text { Ischemia } 1 \mathrm{~h} \text {, } \\
\text { reoxygenation } 3 \mathrm{~h}\end{array}$ & $\begin{array}{l}\text { Flumazenil preconditioning } \\
\qquad 10 \mu \mathrm{mol} / \mathrm{L}\end{array}$ & $\begin{array}{l}\text { Inhibiting ROS/mitochondrial } \\
\text { K(ATP) channel }\end{array}$ & [192] \\
\hline $\begin{array}{l}\text { Chick cardiomyocyte } \\
\text { in vitro }\end{array}$ & $\begin{array}{l}\text { Ischemia } 10 \mathrm{~min} \text {, } \\
\text { reoxygenation } 10 \mathrm{~min}\end{array}$ & $\begin{array}{l}\text { Flumazenil preconditioning } \\
\qquad 10 \mu \mathrm{mol} / \mathrm{L}\end{array}$ & $\begin{array}{l}\text { Inhibiting protein kinase } \\
\mathrm{C} / \text { mitochondrial } \\
\mathrm{K}(\mathrm{ATP}) \text { channel }\end{array}$ & [193] \\
\hline $\begin{array}{l}\text { Chick embryonic } \\
\text { cardiomyocyte in vitro }\end{array}$ & $\begin{array}{l}\text { Hypoxia } 1 \mathrm{~h} \text {, } \\
\text { reoxygenation } 3 \mathrm{~h}\end{array}$ & $\begin{array}{l}\text { Diazepam preconditioning } \\
(100 \mu \mathrm{mol} / \mathrm{L})\end{array}$ & $\begin{array}{l}\text { Inhibiting protein } \\
\text { kinase } C \text { epsilon }\end{array}$ & [194] \\
\hline Isolated rat heart ex vitro & $\begin{array}{l}\text { LPS-induced } \\
\text { ischemia } 5 \mathrm{~h} \text {, } \\
\text { reoxygenation } 20 \mathrm{~min}\end{array}$ & $\begin{array}{c}\text { Diazepam in reperfusion } \\
(3.0 \mu \mathrm{g} / \mathrm{mL})\end{array}$ & $\begin{array}{l}\text { Myocardial functional } \\
\text { parameters and } \\
\text { coronary flow }\end{array}$ & [195] \\
\hline Rat cardiomyocytes in vitro & $\begin{array}{l}\text { Hypoxia } 1 \mathrm{~h} \text {, } \\
\text { subsequent } \\
\text { reoxygenation }\end{array}$ & $\begin{array}{l}\text { Clonazepam in reoxygenation } \\
\qquad(100 \mu \mathrm{mol} / \mathrm{L})\end{array}$ & $\begin{array}{l}\mathrm{Ca}^{2+} \text { accumulation by } \\
\text { reducing } \mathrm{Ca}^{2+} \text { influx and } \\
\text { preserves mitochondrial } \\
\text { membrane potential }\end{array}$ & [196] \\
\hline
\end{tabular}

rats according to the donor rats, PI3K, Akt, antioxidant enzymes (superoxide dismutase), ataxia-telangiectasia mutated kinase (ATM), and phosphorylated histone $\mathrm{H} 2 \mathrm{AX}$ (gamma $\mathrm{H} 2 \mathrm{AX}$ ) were also greatly enhanced. The final index as the markers of DNA damage indicated the potential pathway that GABA attenuated hepatic I/R injury. In vitro, the treatment to the harvested graft of donor rats with GABA receptor agonists for $4 \mathrm{~h}$ of cold ischemia cannot prevent hepatic $I / R$ injury in the orthotopic liver transplantation model or shear stress in the split orthotopic liver transplantation model [188], suggesting that GABA had no direct effect on hepatic I/R injury. In addition, a noteworthy study indicated that flumazenil, an antagonist of benzodiazepine receptors, can improve hepatic encephalopathy produced by hepatic I/R injury [189]. Benzodiazepines are a class of drugs targeting $\mathrm{GABA}_{\mathrm{A}}$ receptor and enhancing GABA to produce effects which are sedative, hypnotic, anxiolytic, anticonvulsant, etc. [190]. The result that flumazenil attenuates the cerebral complication of hepatic I/R injury may be due to its direct interaction with GABA receptor. A recent research had confirmed that $\alpha 1-\gamma 2$ interface of $\mathrm{GABA}_{\mathrm{A}}$ receptor may be the action site of flumazenil [45]. But it was still uncertain whether the effect of flumazenil was related to inhibited GABA pathway mediated by blocking the benzodiazepine signal pathway. In the meanwhile, the effect of flumazenil on hepatic I/R injury had not been explored. Therefore, it was unclear whether it is consistent concerning effects of flumazenil on hepatic I/R injury and its complications (e.g., hepatic encephalopathy). The difference between the probably inhibited GABA pathway and other GABA receptor agonists in attenuating hepatic I/R injury needs further investigations.

6.5. GABA and Myocardial I/R Injury. Myocardial ischemia refers to coronary blood flow reduction which cannot meet their metabolic requests. Myocardial ischemia is characterized by loss of oxygen, accumulations of hydrogen ions and lactate, and ion changes (the decline of $\mathrm{K}^{+}$and the increase of $\mathrm{Na}^{+}$) in the myocardial extracellular fluid [197]. Myocardial ischemia can lead to arrhythmias, sudden death, myocardial infarction, aneurysms, ruptures, and valvular dysfunction of the heart [198]. Reperfusion is the only effective treatment to prevent the pathological process. However, reperfusion has some deleterious consequences including oxygen radicals, $\mathrm{Ca}^{2+}$ loading, and inflammations, which further caused reperfusion-induced arrhythmias, myocardial stunning, microvascular obstruction, and lethal myocardial reperfusion injury [199]. Thus, it is necessary to develop new strategies to prevent the harmful events. GABA has been detected in sympathetic premotor neurons of the medullary raphe controlling sympathetic tone to the heart [200]. Thus, GABA may provide a potential outlet to attenuate myocardial I/R injury through the nervous system. Thirty years ago, Meerson et al. had found that GABA accumulation in the brain by administering the inhibitor of GABA transaminase (sodium valproate) prevented the total duration of arrhythmias and cardiac fibrillation in acute I/R of conscious rats with closed chests [201]. Recently, two studies [202, 203] indicated that the GABA pathway in the nervous system was involved in the cardioprotection against myocardial I/R injury induced by the acute sleep deprivation. Bicuculline, a $\mathrm{GABA}_{\mathrm{A}}$ receptor antagonist, can abolish the effects, and the mechanisms were related to repressing oxidative stress, NO production, and inflammation. In another hand, how GABA can directly affect myocardial I/R injury should also receive special attentions due to confirmed GABA receptors in the heart [204]. Several other studies (Table 2) showed that different benzodiazepine receptor agonists able of enhancing GABA signals remarkably improved indexes of myocardial $\mathrm{I} / \mathrm{R}$ injury in several ways, including reducing $\mathrm{Ca}^{2+}$ influx, oxidation, ATP-dependent potassium (K(ATP)) channels, and protein kinase C. However, it was likely that these benzodiazepines attenuated myocardial I/R injury not through the GABA signal pathway or at least not directly through acting 
on cardiac muscle because it was irreproducible in the isolated heart according to a study [191]. Whether other benzodiazepine receptor agonists targeted peripheral GABA receptors in myocardial cells needs further investigations. In addition, direct effects of GABA on myocardial I/R injury had not been explored.

6.6. Similarities and Differences about the Potential Effects of $G A B A$ on $I / R$ Injury in Different Peripheral Organs. Due to microcirculatory dysfunction by $\mathrm{I} / \mathrm{R}$ potentially triggering multiple organ injuries [3], it is vital to sum up characteristics about the effects of GABA on I/R injury in different peripheral organs (stomach, intestine, kidney, liver, and heart) before appropriately applying GABA or GABA-related drugs in defending I/R injuries. First, in the similarity, the results about the protective effect of GABA on I/R injuries of peripheral organs from the central nervous pathway were consistent, but the role difference between GABA receptors was not utterly identified, needing further investigations. Further, the direct effects of GABA or GABA-related drugs on different peripheral organs were diverse. For instance, there were no direct protective effects of GABA or GABA-related drugs on $\mathrm{I} / \mathrm{R}$ injuries of the stomach and liver, compared with direct protective effects on kidney I/R. However, it was particularly noteworthy that flumazenil, an antagonist of benzodiazepine receptors, can aggregate hepatic I/R injury with the utterly unclarified mechanism which differed from the protective effects of GABA enhancers. In addition, the effects of GABA on I/R injuries of the intestine and heart needed to be further certified.

\section{The Linkage of GABA Molecular Pathway between Central Nervous System and Peripheral Organs in Affecting I/R Injury}

In applying GABA-related drugs to attenuate I/R injury, both roles of GABA in the central nervous system and peripheral organs should be carefully considered in order to avoid inconsistent consequences. According to what was mentioned above, some common molecular pathways in the two regions by GABA enhancers had been identified, including increased signal pathways (e.g., PI3K and AKT), reduced signal pathways (e.g., ROS and inflammation), and restored calcium balance. Although there was still shortage of data in peripheral organs, promising prospects with further researches would be possible for simultaneously improving I/R injuries of the central nervous system and peripheral organs by GABArelated drugs. However, more GABA molecular pathways linking the two regions need be certified. Besides, the effects that would happen to these common GABA molecular pathways of peripheral organs after applying GABA transmission inhibitors to attenuate adult cerebral I/R injury should also be paid attention in next investigations.

\section{The Necessity to Combine GABA-Related Drugs and Molecular Pathways}

Due to many GABA-related drugs able to cross the bloodbrain barrier resulting in possible dual effects on I/R injuries of the central nervous system and peripheral organs by peripheral administrations (e.g., possible effects of some GABA-related drugs by i.p. on peripheral organs in Table 1), it is essential to combine the drug therapy with molecular pathways and the effects in applying GABArelated drugs to I/R injuries of the two regions. Based on this, it was equally important to further confirm accurate common molecular pathways in protective roles on the two regions and exclude inconsistent effects for other molecular pathways in applying GABA-related drugs on I/R injuries of the two regions in the future.

\section{Conclusion}

I/R insults different tissues and organs so that it is still difficult to protect against I/R injuries according to present data. Developing and perfecting potential protective targets against I/R injury are a more effective strategy. GABA, one of the most abundant neurotransmitters, plays inhibitory effect by targeting its receptors ( $\mathrm{A}, \mathrm{B}$, and $\mathrm{C}$ ) to generate hyperpolarization potentials in the adult brain compared with excitatory effects in the immature brain. The increasing number of researches concerning reduced GABA transmission compared with increased glutamate signals occurring in cerebral I/R indicated that GABA could play the key role in the pathology of cerebral I/R injury. Therefore, most researches about GABA and I/R injury focus on the nervous system. In this review, the variations of GABA levels, syntheses, releases, mechanisms, receptors, and signal transmissions occurring during the cerebral I/R process were firstly reviewed from a comprehensive aspect. Alike variations from elevation to reduction in these indexes of the mature brain during I/R injury and the confirmed mechanisms probably provided evidences for the treatment window period. Therefore, strengthening the GABA transmission was a common scheme to prevent cerebral I/R injury in adult. Blocking of the GABA transmission was the method to attenuate cerebral I/R injury of the immature brain. However, new problems are gradually emerging in accumulating studies applying the enhancers of GABA transmission to prevent against cerebral I/R injury, such as dose-effect relationships, beneficial effects of applying antagonists, and multiple mechanisms. First, the relationship between the dose and the effect was a traditional issue and may be resolved by the adjustment of different doses or cotreatments of several lower doses of different drugs. Moreover, some mechanisms in applying different GABA transmission enhancers to attenuate the cerebral I/R injury were found, including improved expressions of GABA receptors; increased NO synthase and PSD95 interaction; activated $\alpha 2-\delta$ subunit of the voltage-dependent $\mathrm{Ca}^{2+}$ channel and $\mathrm{Ca}^{2+} /$ calmodulin-dependent protein kinase II, enhanced proliferation (upregulated $\mathrm{Bcl}-2$ expressions and Bcl-2/Bax ratio); inhibited apoptosis (downregulated expressions of procaspase- 3 and caspase-3) through different pathways (GluR-PSD95-MLK3-JNK3 and PKM $/$ KCC2); reduced glutamate and $\mathrm{LDH}$ levels, inhibiting NMDA receptor/Src-mediated signal; suppressed autophagy by activating Akt, GSK-3 $\beta$, and ERK; neutrophil-directed migration by PI3K; attenuated oxidative stress; decreased intracellular 
$\mathrm{Ca}^{2+}$ contents; and restored contents of BDNF, VEGF, TrkB, NCAM, and Kir3. However, more mechanisms and the accurate application of these drugs in different statuses may be the next challenges for investigators. In contrast, pretreatments or delayed treatments with antagonists to block GABA transmission instead restored motor functions in vivo and increased the tolerance to oxygenglucose deprivation in vitro. These results are obviously different from the results of previous studies in applying enhancers of GABA transmission. The mechanisms are related to calmodulin-phosphorylation of ERK1/2 and targeting $\mathrm{GABA}_{\mathrm{A}}$ receptor $\alpha 5$ subunit, respectively. These researches indicated that the adjustment to the status of different steps in GABA transmission may immunize the cerebral tissue or later repair neurons. In spinal cord I/R injury, the role of GABA had bidirectional effect, making the application more complex and arousing more attentions in the future.

In addition, the roles of GABA in peripheral organs had also been unearthed, including the stomach, intestine, kidney, liver, and heart. As a whole, enhancing GABA functions by GABA or its agonist can prevent I/R injury despite insufficient data (especially in the clinic) through different pathways. The protective effects of GABA were proved dependent on activated nervous functions, such as the stomach, kidney, and heart. In the intestine and liver, the treatment of GABA agonists can directly attenuate I/R injury. However, the corresponding mechanisms in these organs were seldom reported, whether in test models or in the clinic. Besides, during the I/R injury of multiple organs, the applications of drugs (agonists or antagonists based on GABA transmission) should be considered in the whole body. Consequently, in the view of this point, present data are far from enough for applying GABA to clinic treatments.

\section{Abbreviations}

$\begin{array}{ll}\text { Akt: } & \text { Protein kinase B } \\ \text { ATP: } & \text { Adenosine triphosphate } \\ \text { Bax: } & \text { Bcl-2-like protein 4 } \\ \text { Bcl-2: } & \text { B-cell lymphoma-2 } \\ \text { BDNF: } & \text { Brain-derived neurotrophic factor } \\ \text { CREB: } & \text { cAMP-response element binding protein } \\ \text { ERK1/2: } & \text { Extracellular regulated protein kinases 1/2 } \\ \text { FN: } & \text { Fastigial nucleus } \\ \text { GABA: } & \gamma \text {-Aminobutyric acid } \\ \text { GAD: } & \text { Glutamate decarboxylase } \\ \text { GAT: } & \text { GABA transporters } \\ \text { GIRK, Kir3: } & \text { G protein-activated inwardly rectifying } \\ & \text { potassium } \\ \text { GluR: } & \text { Glutamate receptor } \\ \text { GSK-3 } \beta: & \text { Glycogen synthase kinase-3 beta } \\ \text { GSN: } & \text { Greater splanchnic nerve } \\ \text { IIR: } & \text { Intestinal ischemia-reperfusion } \\ \text { IN: } & \text { Interpositus nucleus } \\ \text { I/R: } & \text { Ischemia-reperfusion } \\ \text { JNK: } & \text { 3c-Jun N-terminal kinase 3 } \\ \text { KCC2: } & \text { Potassium chloride cotransporter } \\ \text { LDH: } & \text { Glutamate and lactate dehydrogenase }\end{array}$

LHA: Lateral hypothalamic area

NCAM: $\quad$ Neural cell adhesion molecule

NLK3: $\quad$ Mixed lineage kinase 3

NMDA: $\quad N$-Methyl-D-aspartic acid

NO: $\quad$ Nitric oxide

PI3K: $\quad$ Phosphoinositide 3-kinase

PKM $\zeta$ : $\quad$ Protein kinase $\mathrm{M}$ zeta

PSD95: $\quad$ Postsynaptic density 95

PVN: $\quad$ Paraventricular nucleus

SSADH: $\quad$ Succinic semialdehyde dehydrogenase

tGAD: $\quad$ Truncated glutamate decarboxylase

TrkB: $\quad$ Tyrosine kinase B

tVGAT: Vesicular GABA transporters

VEGF: Vascular endothelial growth factor

VGAT: Vesicular GABA transporters.

\section{Disclosure}

Xiang Zhou was the co-first author.

\section{Conflicts of Interest}

The authors declare that they have no conflict of interest.

\section{Authors' Contributions}

Xiang Zhou contributed equally to this work as Chaoran Chen.

\section{Acknowledgments}

The study was supported by the Chinese Henan Provincial Education Department Project (18B310001), the Natural Science Foundation of China (no. 81703222), the Chinese Henan Province Social Science Planning and DecisionMaking Consulting Project (2018BJC38), the Subsidy for the Project of Innovation and Quality Improvement of Postgraduate Education in Henan University (SYL18060142), and the Henan Province Teacher Education Curriculum and Reform Project (2016-JSJYZD-003).

\section{References}

[1] N. L. Halladin, "Oxidative and inflammatory biomarkers of ischemia and reperfusion injuries," Danish Medical Journal, vol. 62, no. 4, article B5054, 2015.

[2] H. K. Eltzschig and C. D. Collard, "Vascular ischaemia and reperfusion injury," British Medical Bulletin, vol. 70, no. 1, pp. 71-86, 2004.

[3] H. K. Eltzschig and T. Eckle, "Ischemia and reperfusion-from mechanism to translation," Nature Medicine, vol. 17, no. 11, pp. 1391-1401, 2011.

[4] D. Stephenson, T. Yin, E. B. Smalstig et al., "Transcription factor nuclear factor-kappa B is activated in neurons after focal cerebral ischemia," Journal of Cerebral Blood Flow and Metabolism, vol. 20, no. 3, pp. 592-603, 2000.

[5] B. K. Siesjo, "Calcium and ischemic brain damage," European Neurology, vol. 25, no. 1, Supplement 1, pp. 45-56, 1986.

[6] Z. G. Zhang, M. Chopp, C. Zaloga, J. S. Pollock, and U. Förstermann, "Cerebral endothelial nitric oxide synthase 
expression after focal cerebral ischemia in rats," Stroke, vol. 24, no. 12, pp. 2016-2021, 1993.

[7] K. Sun, J. Fan, and J. Han, "Ameliorating effects of traditional Chinese medicine preparation, Chinese materia medica and active compounds on ischemia/reperfusioninduced cerebral microcirculatory disturbances and neuron damage," Acta Pharmaceutica Sinica, vol. 5, no. 1, pp. 8-24, 2015.

[8] D. J. Hausenloy and D. M. Yellon, "The therapeutic potential of ischemic conditioning: an update," Nature Reviews Cardiology, vol. 8, no. 11, pp. 619-629, 2011.

[9] T. Ravingerova, V. Farkasova, L. Griecsova et al., "Remote preconditioning as a novel "conditioning" approach to repair the broken heart: potential mechanisms and clinical applications," Physiological Research, vol. 65, Supplement 1, pp. S55S64, 2016.

[10] I. Andreadou, E. K. Iliodromitis, T. Rassaf, R. Schulz, A. Papapetropoulos, and P. Ferdinandy, "The role of gasotransmitters $\mathrm{NO}, \mathrm{H}_{2} \mathrm{~S}$ and $\mathrm{CO}$ in myocardial ischaemia/reperfusion injury and cardioprotection by preconditioning, postconditioning and remote conditioning," British Journal of Pharmacology, vol. 172, no. 6, pp. 1587-1606, 2015.

[11] M. A. Osuna-Zazuetal, J. A. Ponce-Gomez, and I. Perez-Neri, "Neuroprotective mechanisms of cannabinoids in brain ischemia and neurodegenerative disorders," Investigacion Clinica, vol. 56, no. 2, pp. 188-200, 2015.

[12] A. Partoazar, S. Nasoohi, S. M. Rezayat et al., "Nanoliposome containing cyclosporine A reduced neuroinflammation responses and improved neurological activities in cerebral ischemia/reperfusion in rat," Fundamental \& Clinical Pharmacology, vol. 31, no. 2, pp. 185-193, 2017.

[13] L. Wei, Z. Z. Wei, M. Q. Jiang, O. Mohamad, and S. P. Yu, "Stem cell transplantation therapy for multifaceted therapeutic benefits after stroke," Progress in Neurobiology, vol. 157, no. 10, pp. 49-78, 2017.

[14] N. Pintori, B. Loi, and M. Mereu, "Synthetic cannabinoids: the hidden side of Spice drugs," Behavioural Pharmacology, vol. 28, no. 6, pp. 409-419, 2017.

[15] W. M. Smith, "Cyclosporine: a historical perspective on its role in the treatment of noninfectious uveitis," Journal of Ocular Pharmacology and Therapeutics, vol. 33, no. 4, pp. 247-262, 2017.

[16] S. C. Lee, J. O. Kim, and S. J. Kim, "Secretome from human adipose-derived stem cells protects mouse liver from hepatic ischemia-reperfusion injury," Surgery, vol. 157, no. 5, pp. 934-943, 2015.

[17] J. R. Cooper, F. E. Bloom, and R. H. Roth, The Biochemical Basis of Neuropharmacology, Oxford University Press, 2003.

[18] W. G. Van der Kloot and J. Robbins, "The effects of gammaaminobutyric acid and picrotoxin on the junctional potential and the contraction of crayfish muscle," Experientia, vol. 15, no. 1, pp. 35-36, 1959.

[19] Y. Ben-Ari, I. Khalilov, K. T. Kahle, and E. Cherubini, "The GABA excitatory/inhibitory shift in brain maturation and neurological disorders," The Neuroscientist, vol. 18, no. 5, pp. 467-486, 2012.

[20] M. Watanabe, K. Maemura, K. Kanbara, T. Tamayama, and H. Hayasaki, "GABA and GABA receptors in the central nervous system and other organs," International Review of Cytology, vol. 213, pp. 1-47, 2002.
[21] S. L. Mclntire, E. Jorgensen, and H. R. Horvitz, "Genes required for GABA function in Caenorhabditis elegans," Nature, vol. 364, no. 6435, pp. 334-337, 1993.

[22] K. Obata, M. Oide, and H. Tanaka, "Excitatory and inhibitory actions of GABA and glycine on embryonic chick spinal neurons in culture," Brain Research, vol. 144, no. 1, pp. 179-184, 1978.

[23] G. Sperk, S. Furtinger, C. Schwarzer, and S. Pirker, "GABA and its receptors in epilepsy," Advances in Experimental Medicine and Biology, vol. 548, no. 3, pp. 92-103, 2004.

[24] S. J. Kish, A. Rajput, J. Gilbert et al., "Elevated $\gamma$-aminobutyric acid level in striatal but not extrastriatal brain regions in Parkinson's disease: Correlation with striatal dopamine loss," Annals of Neurology, vol. 20, no. 1, pp. 26-31, 1986.

[25] U. Roy, L. Stute, C. Höfling et al., "Sex- and age-specific modulation of brain GABA levels in a mouse model of Alzheimer's disease," Neurobiology of Aging, vol. 62, no. 2, pp. 168-179, 2018.

[26] Y. T. Hsu, Y. G. Chang, and Y. Chern, "Insights into $\mathrm{GABA}_{\mathrm{A}}$ ergic system alteration in Huntington's disease," Open Biology, vol. 8, no. 12, article 180165, 2018.

[27] R. R. Schür, L. W. R. Draisma, J. P. Wijnen et al., "Brain GABA levels across psychiatric disorders: A systematic literature review and meta-analysis of ${ }^{1} \mathrm{H}$-MRS studies," Human Brain Mapping, vol. 37, no. 9, pp. 3337-3352, 2016.

[28] J. U. Blicher, J. Near, E. Næss-Schmidt et al., "GABA levels are decreased after stroke and GABA changes during rehabilitation correlate with motor improvement," Neurorehabilitation and Neural Repair, vol. 29, no. 3, pp. 278-286, 2014.

[29] G. Cao, R. A. E. Edden, F. Gao et al., "Reduced GABA levels correlate with cognitive impairment in patients with relapsing-remitting multiple sclerosis," European Radiology, vol. 28, no. 3, pp. 1140-1148, 2018.

[30] S. L. Erdo and J. R. Wolff, " $\gamma$-aminobutyric acid outside the mammalian brain," Journal of Neurochemistry, vol. 54, no. 2, pp. 363-372, 1990.

[31] I. Purwana, J. Zheng, X. Li et al., "GABA promotes human $\beta$ Cell Proliferation and modulates glucose homeostasis," Diabetes, vol. 63, no. 12, pp. 4197-4205, 2014.

[32] J. Tian, J. Yong, H. Dang, and D. L. Kaufman, “Oral GABA treatment downregulates inflammatory responses in a mouse model of rheumatoid arthritis," Autoimmunity, vol. 44, no. 6, pp. 465-470, 2011.

[33] S. Kobuchi, T. Shintani, T. Sugiura et al., "Renoprotective effects of $\gamma$-aminobutyric acid on ischemia/reperfusioninduced renal injury in rats," European Journal of Pharmacology, vol. 623, no. 1-3, pp. 113-118, 2009.

[34] Y. Chen, L. Zhang, J. Ni et al., "LLDT-8 protects against cerebral ischemia/reperfusion injury by suppressing post-stroke inflammation," Journal of Pharmacological Sciences, vol. 131, no. 2, pp. 131-137, 2016.

[35] Y. Xie, D. Zhao, P. Dong, and L. Lai, "Macrophage-targeting Fasudil treatment protects liver from the ischemia/reperfusion injury by promoting M2 macrophage polarization," Bioscience Reports, vol. 38, no. 2, 2018.

[36] D. F. Bu, M. G. Erlander, B. C. Hitz et al., "Two human glutamate decarboxylases, 65-kDa GAD and 67-kDa GAD, are each encoded by a single gene," Proceedings of the National Academy of Sciences of the United States of America, vol. 89, no. 6, pp. 2115-2119, 1992. 
[37] N. J. K. Tillakaratne, L. Medina-Kauwe, and K. M. Gibson, "Gamma-aminobutyric acid (GABA) metabolism in mammalian neural and nonneural tissues," Comparative Biochemistry and Physiology Part A: Physiology, vol. 112, no. 2, pp. 247-263, 1995.

[38] A. C. Thomas-Reetz and P. De Camilli, "A role for synaptic vesicles in non-neuronal cells: clues from pancreatic beta cells and from chromaffin cells," The FASEB Journal, vol. 8, no. 2, pp. 209-216, 1994.

[39] K. Kuriyama and P. Y. Sze, "Blood-brain barrier to $\mathrm{H}^{3}-\gamma$-aminobutyric acid in normal and amino oxyacetic acid-treated animals," Neuropharmacology, vol. 10, no. 1, pp. 103-108, 1971.

[40] H. Takanaga, S. Ohtsuki, K.-I. Hosoya, and T. Terasaki, "GAT2/BGT-1 as a system responsible for the transport of $\gamma$-aminobutyric acid at the mouse blood-brain barrier," Journal of Cerebral Blood Flow \& Metabolism, vol. 21, no. 10, pp. 1232-1239, 2001.

[41] S. Schipper, M. W. Aalbers, K. Rijkers et al., "Erratum to: Tonic $\mathrm{GABA}_{\mathrm{A}}$ receptors as potential target for the treatment of temporal lobe epilepsy," Molecular Neurobiology, vol. 53, no. 8, pp. 5266-5268, 2016.

[42] M. Watanabe, H. Wake, A. J. Moorhouse, and J. Nabekura, "Clustering of neuronal $\mathrm{K}+-\mathrm{Cl}$ - cotransporters in lipid rafts by tyrosine phosphorylation," The Journal of Biological Chemistry, vol. 284, no. 41, pp. 27980-27988, 2009.

[43] M. Jembrek and J. Vlainic, "GABA receptors: pharmacological potential and pitfalls," Current Pharmaceutical Design, vol. 21, no. 34, pp. 4943-4959, 2015.

[44] E. Sigel and M. Ernst, "The Benzodiazepine Binding Sites of

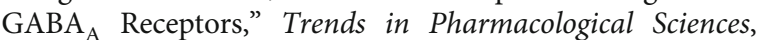
vol. 39, no. 7, pp. 659-671, 2018.

[45] S. Zhu, C. M. Noviello, J. Teng, R. M. Walsh, J. J. Kim, and R. E. Hibbs, "Structure of a human synaptic $\mathrm{GABA}_{\mathrm{A}}$ receptor," Nature, vol. 559, no. 7712, pp. 67-72, 2018.

[46] S. Kickinger, E. Hellsberg, B. Frølund, A. Schousboe, G. F. Ecker, and P. Wellendorph, "Structural and molecular aspects of betaine-GABA transporter 1 (BGT1) and its relation to brain function," Neuropharmacology, vol. 162, no. 19, pp. 30170-30174, 2019.

[47] L. Savtchenko, M. Megalogeni, D. A. Rusakov, M. C. Walker, and I. Pavlov, "Synaptic GABA release prevents GABA transporter type-1 reversal during excessive network activity," Nature Communications, vol. 6, no. 1, article 6597, Article ID BFncomms7597, 2015.

[48] N. J. Allen, D. J. Rossi, and D. Attwell, "Sequential release of GABA by exocytosis and reversed uptake leads to neuronal swelling in simulated ischemia of hippocampal slices," The Journal of Neuroscience, vol. 24, no. 15, pp. 38373849, 2004.

[49] L. Borden, "GABA transporter heterogeneity: pharmacology and cellular localization," Neurochemistry International, vol. 29, no. 4, pp. 335-356, 1996.

[50] D. Ravasz, G. Kacso, V. Fodor, K. Horvath, V. Adam-Vizi, and C. Chinopoulos, "Catabolism of GABA, succinic semialdehyde or gamma-hydroxybutyrate through the GABA shunt impair mitochondrial substrate-level phosphorylation," Neurochemistry International, vol. 109, no. 10, pp. 41-53, 2017.

[51] Q. Tu, R. Wang, B. Ding, W. Zhong, and H. Cao, "Protective and antioxidant effect of Danshen polysaccharides on cerebral ischemia/reperfusion injury in rats," International Jour- nal of Biological Macromolecules, vol. 60, no. 9, pp. 268271, 2013.

[52] J. Pan, A.-A. Konstas, B. Bateman, G. A. Ortolano, and J. PileSpellman, "Reperfusion injury following cerebral ischemia: pathophysiology, MR imaging, and potential therapies," Neuroradiology, vol. 49, no. 2, pp. 93-102, 2007.

[53] P. Sahota and S. I. Savitz, "Investigational therapies for ischemic stroke: neuroprotection and neurorecovery," Neurotherapeutics, vol. 8, no. 3, pp. 434-451, 2011.

[54] J. Zhou, M. Li, W.-F. Jin, X.-H. Li, and Y.-Y. Zhang, "Role of $\mathrm{NF}-\kappa \mathrm{B}$ on neurons after cerebral ischemia reperfusion," International Journal of Pharmacology, vol. 14, no. 4, pp. 451-459, 2018.

[55] N. Krisanova, N. Pozdnyakova, A. Pastukhov et al., "Vitamin D3 deficiency in puberty rats causes presynaptic malfunctioning through alterations in exocytotic release and uptake of glutamate/GABA and expression of EAAC-1/GAT-3 transporters," Food and Chemical Toxicology, vol. 123, no. 1, pp. 142-150, 2019.

[56] C. Ouyang, L. Guo, Q. Lu, X. Xu, and H. Wang, "Enhanced activity of GABA receptors inhibits glutamate release induced by focal cerebral ischemia in rat striatum," Neuroscience Letters, vol. 420, no. 2, pp. 174-178, 2007.

[57] N. Nakata, H. Kato, and K. Kogure, "Effects of repeated cerebral ischemia on extracellular amino acid concentrations measured with intracerebral microdialysis in the gerbil hippocampus," Stroke, vol. 24, no. 3, pp. 458-463, 1993.

[58] Q. Huang, C. Li, N. Xia et al., "Neurochemical changes in unilateral cerebral hemisphere during the subacute stage of focal cerebral ischemia-reperfusion in rats: An ex vivo ${ }^{1} \mathrm{H}$ magnetic resonance spectroscopy study," Brain Research, vol. 1684, no. 4, pp. 67-74, 2018.

[59] L. Ruan, Y. Wang, S.-c. Chen et al., "Metabolite changes in the ipsilateral and contralateral cerebral hemispheres in rats with middle cerebral artery occlusion," Neural Regeneration Research, vol. 12, no. 6, pp. 931-937, 2017.

[60] K. Figlewski, H. Andersen, T. Stærmose, P. von WeitzelMudersbach, J. F. Nielsen, and J. U. Blicher, "Decreased GABA levels in the symptomatic hemisphere in patients with transient ischemic attack," Heliyon, vol. 4, no. 9, article e00790, 2018.

[61] Y. Zhang, G. Q. Liu, X. D. Liu, and X. Q. Xiao, "Efflux transport of $[3 \mathrm{H}] \mathrm{GABA}$ across blood-brain barrier after cerebral ischemia-reperfusion in rats," Zhongguo Yao Li Xue Bao, vol. 20, no. 3, pp. 223-226, 1999.

[62] Z. Qian, Y. Lin, J. Xing, Y. Qiu, and L. Ren, "Expression and functions of glutamate and $\gamma$-aminobutyric acid transporters in ischemic models," Molecular Medicine Reports, vol. 17, no. 6, pp. 8196-8202, 2018.

[63] Y. Li, G. D. Blanco, Z. Lei, and Z. C. Xu, "Increased GAD expression in the striatum after transient cerebral ischemia," Molecular and Cellular Neurosciences, vol. 45, no. 4, pp. 370-377, 2010.

[64] M. Saji, M. Cohen, A. D. Blau, T. C. Wessel, and B. T. Volpe, "Transient forebrain ischemia induces delayed injury in the substantia nigra reticulata: degeneration of GABA neurons, compensatory expression of GAD mRNA," Brain Research, vol. 643, no. 1-2, pp. 234-244, 1994.

[65] B. Lin, S. Levy, A. P. Raval, M. A. Perez-Pinzon, and R. A. DeFazio, "Forebrain ischemia triggers GABAergic system degeneration in substantia nigra at chronic stages in rats," 
Cardiovascular Psychiatry and Neurology, vol. 2010, Article ID 506952, 16 pages, 2010.

[66] F. L. Xu, C. L. Zhu, and X. Y. Wang, "Developmental changes of glutamate acid decarboxylase-67 in mouse brain after hypoxia ischemia," Neuroscience Bulletin, vol. 22, no. 1, pp. 4751, 2006.

[67] C. Buddhala, M. Suarez, J. Modi et al., "Calpain cleavage of brain glutamic acid decarboxylase 65 is pathological and impairs GABA neurotransmission," PloS One, vol. 7, no. 3, article e33002, 2012.

[68] R. Vemuganti, "Decreased expression of vesicular GABA transporter, but not vesicular glutamate, acetylcholine and monoamine transporters in rat brain following focal ischemia," Neurochemistry International, vol. 47, no. 1-2, pp. 136-142, 2005.

[69] C. Frahm, G. Siegel, S. Grass, and O. W. Witte, "Stable expression of the vesicular GABA transporter following photothrombotic infarct in rat brain," Neuroscience, vol. 140, no. 3, pp. 865-877, 2006.

[70] J. R. Gomes, A. C. Lobo, C. V. Melo et al., "Cleavage of the vesicular GABA transporter under excitotoxic conditions is followed by accumulation of the truncated transporter in nonsynaptic sites," The Journal of Neuroscience, vol. 31, no. 12, pp. 4622-4635, 2011.

[71] T. C. Kang, S. K. Park, I. K. Hwang et al., "Spatial and temporal alterations in the GABA shunt in the gerbil hippocampus following transient ischemia," Brain Research, vol. 944, no. 12, pp. 10-18, 2002.

[72] H. Monnerie and P. D. Le Roux, "Reduced dendrite growth and altered glutamic acid decarboxylase (GAD) 65- and 67$\mathrm{kDa}$ isoform protein expression from mouse cortical GABAergic neurons following excitotoxic injury _in vitro_ ," Experimental Neurology, vol. 205, no. 2, pp. 367-382, 2007.

[73] B. Alicke and R. D. Schwartz-Bloom, "Rapid Down-Regulation of $\mathrm{GABA}_{\mathrm{A}}$ Receptors in the Gerbil Hippocampus Following Transient Cerebral Ischemia," Journal of Neurochemistry, vol. 65, no. 6, pp. 2808-2811, 1995.

[74] M. Mele, L. Ribeiro, A. R. Inácio, T. Wieloch, and C. B. Duarte, "GABA $A_{A}$ receptor dephosphorylation followed by internalization is coupled to neuronal death in in vitro ischemia," Neurobiology of Disease, vol. 65, no. 5, pp. 220-232, 2014.

[75] M. Mele, M. C. Aspromonte, and C. B. Duarte, "Downregulation of $\mathrm{GABA}_{\mathrm{A}}$ receptor recycling mediated by HAP1 contributes to neuronal death in in vitro brain ischemia," Molecular Neurobiology, vol. 54, no. 1, pp. 45-57, 2017.

[76] J. T. Costa, M. Mele, M. S. Baptista et al., "Gephyrin cleavage in in vitro brain ischemia decreases $\mathrm{GABA}_{\mathrm{A}}$ receptor clustering and contributes to neuronal death," Molecular Neurobiology, vol. 53, no. 6, pp. 3513-3527, 2016.

[77] D. J. Rodriguez Gil, C. Carmona, G. Negri, and S. Fiszer de Plazas, "Hypoxia differentially reduces $\mathrm{GABA}_{\mathrm{A}}$ receptor density during embryonic chick optic lobe development," Neurochemical Research, vol. 29, no. 4, pp. 681-686, 2004.

[78] H. Li, R. E. Siegel, and R. D. Schwartz, "Rapid decline of $\mathrm{GABA}_{\mathrm{A}}$ receptor subunit mRNA expression in hippocampus following transient cerebral ischemia in the gerbil," Hippocampus, vol. 3, no. 4, pp. 527-537, 1993.

[79] S. Montori, S. DosAnjos, A. Poole et al., "Differential effect of transient global ischaemia on the levels of $\gamma$-aminobutyric acid type $A\left(G_{A B A}\right)$ receptor subunit mRNAs in young and older rats," Neuropathology and Applied Neurobiology, vol. 38, no. 7, pp. 710-722, 2012.

[80] T. Neumann-Haefelin, F. Bosse, C. Redecker, H. W. Müller, and $\mathrm{O} . \mathrm{W}$. Witte, "Upregulation of $\mathrm{GABA}_{\mathrm{A}}$-receptor $\alpha 1$ and $\alpha 2$-subunit mRNAs following ischemic cortical lesions in rats," Brain research, vol. 816, no. 1, pp. 234-237, 1999.

[81] T. Neumann-Haefelin, J. F. Staiger, C. Redecker et al., "Immunohistochemical evidence for dysregulation of the GABAergic system ipsilateral to photochemically induced cortical infarcts in rats," Neuroscience, vol. 87, no. 4, pp. 871-879, 1998.

[82] A. Zepeda, F. Sengpiel, M. A. Guagnelli, L. Vaca, and C. Arias, "Functional reorganization of visual cortex maps after ischemic lesions is accompanied by changes in expression of cytoskeletal proteins and NMDA and $\mathrm{GABA}_{\mathrm{A}}$ receptor subunits," The Journal of Neuroscience, vol. 24, no. 8, pp. 1812-1821, 2004.

[83] E. A. Kharlamov, K. L. Downey, P. I. Jukkola, D. R. Grayson, and K. M. Kelly, "Expression of $\mathrm{GABA}_{\mathrm{A}}$ receptor $\alpha_{1}$ subunit mRNA and protein in rat neocortex following photothrombotic infarction," Brain Research, vol. 1210, no. 5, pp. 2938, 2008.

[84] F. Vollenweider, K. Bendfeldt, W. Maetzler, U. Otten, and C. Nitsch, "GABA $\mathrm{B}_{\mathrm{B}}$ receptor expression and cellular localization in gerbil hippocampus after transient global ischemia," Neuroscience Letters, vol. 395, no. 2, pp. 118-123, 2006.

[85] P. J. Maier, K. Zemoura, M. A. Acuña, G. E. Yévenes, H. U. Zeilhofer, and D. Benke, "Ischemia-like oxygen and glucose deprivation mediates down-regulation of cell surface $\gamma$-aminobutyric $\operatorname{acid}_{B}$ receptors via the endoplasmic reticulum (ER) stress-induced transcription factor CCAAT/enhancerbinding protein (C/EBP)-homologous protein (CHOP)," Journal of Biological Chemistry, vol. 289, no. 18, pp. 1289612907, 2014.

[86] S. M. Miller, S. M. Sullivan, Z. Ireland, K. K. Chand, P. B. Colditz, and S. T. Bjorkman, "Neonatal seizures are associated with redistribution and loss of $\mathrm{GABA}_{\mathrm{A}} \alpha$-subunits in the hypoxic-ischaemic pig," Journal of Neurochemistry, vol. 139, no. 3, pp. 471-484, 2016.

[87] C. Sommer, R. Kollmar, S. Schwab, M. Kiessling, and W. R. Schäbitz, "Exogenous brain-derived neurotrophic factor prevents postischemic downregulation of $\left[{ }^{3} \mathrm{H}\right]$ muscimol binding to $\mathrm{GABA}_{\mathrm{A}}$ receptors in the cortical penumbra," Molecular brain research, vol. 111, no. 1-2, pp. 24-30, 2003.

[88] K. Frauenknecht, K. Plaschke, and C. Sommer, "Transient oligemia is associated with long-term changes in binding densities of cortical inhibitory $\mathrm{GABA}_{\mathrm{A}}$ receptors in the rat brain," Brain Research, vol. 1271, no. 5, pp. 95-102, 2009.

[89] C. Sommer, A. Fahrner, and M. Kiessling, "Postischemic neuroprotection in the ischemia-tolerant state gerbil hippocampus is associated with increased ligand binding to inhibitory GABA $_{\mathrm{A}}$ receptors," Acta Neuropathologica, vol. 105, no. 3, pp. 197-202, 2003.

[90] Z. C. Xu and W. A. Pulsinelli, "Responses of CA1 pyramidal neurons in rat hippocampus to transient forebrain ischemia: an in vivo intracellular recording study," Neuroscience Letters, vol. 171, no. 1-2, pp. 187-191, 1994.

[91] H. B. Verheul, F.-E. Leeuw, G. Scholten, C. A. F. Tulleken, F. H. L. Silva, and W. E. J. M. Ghijsen, "GABA ${ }_{\mathrm{A}}$ receptor function in the early period after transient forebrain ischaemia in the rat," The European Journal of Neuroscience, vol. 5, no. 7, pp. 955-960, 1993. 
[92] P. Congar, R. Khazipov, and Y. Ben-Ari, "Direct demonstration of functional disconnection by anoxia of inhibitory interneurons from excitatory inputs in rat hippocampus," Journal of Neurophysiology, vol. 73, no. 1, pp. 421-426, 1995.

[93] N. Jaenisch, O. W. Witte, and C. Frahm, "Downregulation of potassium chloride cotransporter KCC2 after transient focal cerebral ischemia," Stroke, vol. 41, no. 3, pp. e151-e159, 2010.

[94] T. Mittmann, M. Qu, K. Zilles, and H. J. Luhmann, "Longterm cellular dysfunction after focal cerebral ischemia: in vitro analyses," Neuroscience, vol. 85, no. 1, pp. 15-27, 1998.

[95] R. Z. Zhan, J. V. Nadler, and R. D. Schwartz-Bloom, "Depressed responses to applied and synaptically-released GABA in CA1 pyramidal cells, but not in CA1 interneurons, after transient forebrain ischemia," Journal of Cerebral Blood Flow and Metabolism, vol. 26, no. 1, pp. 112-124, 2005.

[96] R. Liang, Z. P. Pang, P. Deng, and Z. C. Xu, "Transient enhancement of inhibitory synaptic transmission in hippocampal CA1 pyramidal neurons after cerebral ischemia," Neuroscience, vol. 160, no. 2, pp. 412-418, 2009.

[97] R. D. Schwartz-Bloom and R. Sah, " $\gamma$-Aminobutyric acidA neurotransmission and cerebral ischemia," Journal of Neurochemistry, vol. 77, no. 2, pp. 353-371, 2001.

[98] W. Li, R. Huang, Z. Chen, L. J. Yan, J. W. Simpkins, and S. H. Yang, "PTEN degradation after ischemic stroke: a doubleedged sword," Neuroscience, vol. 274, no. 8, pp. 153-161, 2014.

[99] P. A. Steen, "Barbiturates in neuroanesthesia and neurointensive care," Agressologie, vol. 32, no. 6-7, pp. 323-325, 1991.

[100] J. Liu, J. Zhang, L.-N. Wang, and Cochrane Stroke Group, "Gamma aminobutyric acid (GABA) receptor agonists for acute stroke," Cochrane Database of Systematic Reviews, vol. 10, no. 2, article CD009622, 2018.

[101] M. B. Maneyapanda, Z. L. McCormick, C. Marciniak, and C. Reger, "Long-Term Dosing of Intrathecal Baclofen in the Treatment of Spasticity After Acquired Brain Injury," PM\&R, vol. 9, no. 6, pp. 556-562, 2017.

[102] A. B. Gekht, L. S. Kanaeva, A. S. Avedisova et al., "Possible applications of rac-hopantenic acid in the treatment of anxiety and depressive disorders in patients with chronic cerebral ischemia," Zh Nevrol Psikhiatr Im S S Korsakova, vol. 116, no. 11, pp. 45-57, 2016.

[103] T. A. Voronina and S. A. Litvinova, "Pharmacological effects and clinical application of pantogam and pantogam active," Zhurnal Nevrologii i Psikhiatrii Imeni S.S. Korsakova, vol. 117, no. 8, pp. 132-139, 2017.

[104] O. V. Vorob'eva and V. V. Rusaya, "Pharmacotherapy of anxiety disorders in patients with chronic cerebral ischemia," Zhurnal Nevrologii i Psikhiatrii Im. S.S. Korsakova, vol. 116, no. 12. Vyp. 2, pp. 49-55, 2016.

[105] K. Madden, W. Clark, and N. Lessov, "Failure of ischemic neuroprotection by potentiators of gamma-aminobutyric acid," Clinical Medicine \& Research, vol. 1, no. 2, pp. 119124, 2003.

[106] L. Ricci, M. Valoti, G. Sgaragli, and M. Frosini, “Taurine-like GABA aminotransferase inhibitors prevent rabbit brain slices against oxygen-glucose deprivation-induced damage," Amino Acids, vol. 42, no. 6, pp. 2139-2147, 2012.

[107] D.-S. Kim, S.-E. Kwak, J.-E. Kim, M. H. Won, and T.-C. Kang, "The co-treatments of vigabatrin and $\mathrm{P}_{2} \mathrm{X}$ receptor antago- nists protect ischemic neuronal cell death in the gerbil hippocampus," Brain Research, vol. 1120, no. 1, pp. 151-160, 2006.

[108] A. Sarnowska, M. Beresewicz, B. Zablocka, and K. Domanska-Janik, "Diazepam neuroprotection in excitotoxic and oxidative stress involves a mitochondrial mechanism additional to the $\mathrm{GABA}_{\mathrm{A}} \mathrm{R}$ and hypothermic effects," Neurochemistry International, vol. 55, no. 1-3, pp. 164-173, 2009.

[109] L. Ricci, M. Valoti, G. Sgaragli, and M. Frosini, "Neuroprotection afforded by diazepam against oxygen/glucose deprivation- induced injury in rat cortical brain slices," European Journal of Pharmacology, vol. 561, no. 1-3, pp. 80-84, 2007.

[110] L. M. Davies, C. L. MacLellan, D. R. Corbett, and F. Colbourne, "Post-ischemic diazepam does not reduce hippocampal CA1 injury and does not improve hypothermic neuroprotection after forebrain ischemia in gerbils," Brain Research, vol. 1013, no. 2, pp. 223-229, 2004.

[111] C. Costa, G. Leone, E. Saulle, F. Pisani, G. Bernardi, and P. Calabresi, "Coactivation of $\mathrm{GABA}_{\mathrm{A}}$ and $\mathrm{GABA}_{\mathrm{B}}$ Receptor results in neuroprotection during in vitro ischemia," Stroke, vol. 35, no. 2, pp. 596-600, 2004.

[112] M. H. Kelley, J. Ortiz, K. Shimizu, H. Grewal, N. Quillinan, and P. S. Herson, "Alterations in Purkinje cell GABA A $_{\mathrm{A}}$ receptor pharmacology following oxygen and glucose deprivation and cerebral ischemia reveal novel contribution of $\beta 1$-subunit-containing receptors," The European Journal of Neuroscience, vol. 37, no. 4, pp. 555-563, 2013.

[113] M. K. Oh, K. J. Yoon, Y. T. Lee et al., "Effect of zolpidem on functional recovery in a rat model of ischemic stroke," The Journal of International Medical Research, vol. 46, no. 1, pp. 249-257, 2017.

[114] H. Wang, S. Liu, H. Wang, G. Wang, and A. Zhu, "The effect of propofol postconditioning on the expression of $\mathrm{K}^{+}-\mathrm{Cl}^{-}$-cotransporter 2 in GABAergic inhibitory interneurons of acute ischemia/reperfusion injury rats," Brain Research, vol. 1597, no. 2, pp. 210-219, 2015.

[115] C. Y. Yang, S. Y. Liu, H. Y. Wang et al., "Neuroprotection by propofol post-conditioning: focus on PKM /KCC2 pathway activity," Cellular and Molecular Neurobiology, vol. 38, no. 3, pp. 691-701, 2018.

[116] T. Ogura, T. Hamada, T. Matsui et al., "Neuroprotection by JM-1232(-) against oxygen-glucose deprivation-induced injury in rat hippocampal slice culture," Brain Research, vol. 1594, no. 1, pp. 52-60, 2015.

[117] P. Nagakannan, B. D. Shivasharan, B. S. Thippeswamy, and V. P. Veerapur, "Effect of tramadol on behavioral alterations and lipid peroxidation after transient forebrain ischemia in rats," Toxicology Mechanisms and Methods, vol. 22, no. 9, pp. 674-678, 2012.

[118] X. Mao, C. Ji, C. Sun et al., "Topiramate attenuates cerebral ischemia/reperfusion injury in gerbils via activating GABAergic signaling and inhibiting astrogliosis," Neurochemistry International, vol. 60, no. 1, pp. 39-46, 2012.

[119] C. Zhou, C. Li, H. M. Yu, F. Zhang, D. Han, and G. Y. Zhang, "Neuroprotection of $\gamma$-aminobutyric acid receptor agonists via enhancing neuronal nitric oxide synthase (Ser847) phosphorylation through increased neuronal nitric oxide synthase and PSD95 interaction and inhibited protein phosphatase activity in cerebral ischemia," Journal of Neuroscience Research, vol. 86, no. 13, pp. 2973-2983, 2008. 
[120] F. Zhang, C. Li, R. Wang et al., "Activation of GABA receptors attenuates neuronal apoptosis through inhibiting the tyrosine phosphorylation of NR2A by Src after cerebral ischemia and reperfusion," Neuroscience, vol. 150, no. 4, pp. 938949, 2007.

[121] J. Xu, C. Li, X. H. Yin, and G. Y. Zhang, "Additive neuroprotection of $\mathrm{GABA}_{\mathrm{A}}$ and $\mathrm{GABA}_{\mathrm{B}}$ receptor agonists in cerebral ischemic injury via PI-3K/Akt pathway inhibiting the ASK1-JNK cascade," Neuropharmacology, vol. 54, no. 7, pp. 1029-1040, 2008.

[122] D. Han, Q.-G. Zhang, C. L. Yong-Liu et al., "Co-activation of GABA receptors inhibits the JNK3 apoptotic pathway via the disassembly of the GluR6-PSD95-MLK3 signaling module in cerebral ischemic-reperfusion," FEBS Letters, vol. 582, no. 9, pp. 1298-1306, 2008.

[123] E. Vavers, L. Zvejniece, B. Svalbe et al., "The neuroprotective effects of R-phenibut after focal cerebral ischemia," Pharmacological Research, vol. 113, article S1043661815301225, Part B, pp. 796-801, 2016.

[124] A. M. Babcock, A. Everingham, C. M. Paden, and M. Kimura, "Baclofen is neuroprotective and prevents loss of calcium/calmodulin-dependent protein kinase II immunoreactivity in the ischemic gerbil hippocampus," Journal of Neuroscience Research, vol. 67, no. 6, pp. 804-811, 2002.

[125] L. Liu, C. J. Li, Y. Lu et al., "Baclofen mediates neuroprotection on hippocampal CA1 pyramidal cells through the regulation of autophagy under chronic cerebral hypoperfusion," Scientific Reports, vol. 5, no. 1, article 14474, 2015.

[126] Y. Lu, C. J. Li, C. Chen et al., "Activation of $\mathrm{GABA}_{\mathrm{B} 2}$ subunits alleviates chronic cerebral hypoperfusion-induced anxietylike behaviours: a role for BDNF signalling and Kir3 channels," Neuropharmacology, vol. 110, Part A, pp. 308-321, 2016.

[127] K. R. Dave, C. Lange-Asschenfeldt, A. P. Raval et al., "Ischemic preconditioning ameliorates excitotoxicity by shifting glutamate $/ \gamma$-aminobutyric acid release and biosynthesis," Journal of Neuroscience Research, vol. 82, no. 5, pp. 665673, 2005.

[128] M. J. Rane, D. Gozal, W. Butt et al., " $\gamma$-amino butyric acid type $\mathrm{B}$ receptors stimulate neutrophil chemotaxis during ischemia-reperfusion," Journal of Immunology, vol. 174, no. 11, pp. 7242-7249, 2005.

[129] E. D. Hall, T. J. Fleck, and J. A. Oostveen, "Comparative neuroprotective properties of the benzodiazepine receptor full agonist diazepam and the partial agonist PNU-101017 in the gerbil forebrain ischemia model," Brain Research, vol. 798, no. 1-2, pp. 325-329, 1998.

[130] J. S. Tauskela, H. Fang, M. Hewitt et al., "Elevated synaptic activity preconditions neurons against an in Vitro model of ischemia," The Journal of Biological Chemistry, vol. 283, no. 50, pp. 34667-34676, 2008.

[131] E. M. Lake, J. Chaudhuri, L. Thomason et al., "The effects of delayed reduction of tonic inhibition on ischemic lesion and sensorimotor function," Journal of Cerebral Blood Flow and Metabolism, vol. 35, no. 10, pp. 1601-1609, 2015.

[132] W. M. He, L. Ying-Fu, H. Wang, and Y. P. Peng, "Delayed treatment of $\alpha 5 \mathrm{GABA}_{\mathrm{A}}$ receptor inverse agonist improves functional recovery by enhancing neurogenesis after cerebral ischemia-reperfusion injury in rat MCAO model," Scientific Reports, vol. 9, no. 1, article 2287, p. 2287, 2019.

[133] C. Alia, C. Spalletti, S. Lai, A. Panarese, S. Micera, and M. Caleo, "Reducing $\mathrm{GABA}_{\mathrm{A}}$-mediated inhibition improves forelimb motor function after focal cortical stroke in mice," Scientific Reports, vol. 6, no. 1, article 37823, 2016.

[134] S. Robinson, Q. Li, A. Dechant, and M. L. Cohen, "Neonatal loss of gamma-aminobutyric acid pathway expression after human perinatal brain injury," Journal of Neurosurgery, vol. 104, Supplement 6, pp. 396-408, 2006.

[135] P. Andiné, M. Sandberg, R. Bågenholm, A. Lehmann, and H. Hagberg, "Intra- and extracellular changes of amino acids in the cerebral cortex of the neonatal rat during hypoxicischemia," Developmental Brain Research, vol. 64, no. 1-2, pp. 115-120, 1991.

[136] A. Fukuda, K. Muramatsu, A. Okabe et al., "Changes in intracellular $\mathrm{Ca}^{2+}$ induced by $\mathrm{GABA}_{\mathrm{A}}$ receptor activation and reduction in $\mathrm{Cl}^{-}$gradient in neonatal rat neocortex," Journal of Neurophysiology, vol. 79, no. 1, pp. 439-446, 1998.

[137] Q. A. Gillani, A. Akbar, M. Ali, and F. Iqbal, "Gender-specific effects of CGP 55845, GABA ${ }_{B}$ receptor antagonist, on neuromuscular coordination, learning and memory formation in albino mouse following neonatal hypoxia-ischemia insult," Neurological Sciences, vol. 36, no. 6, pp. 961-969, 2015.

[138] Q. Gillani, M. Ali, and F. Iqbal, "Effect of $\mathrm{GABA}_{\mathrm{B}}$ receptor antagonists (CGP 35348 and CGP 55845) on serum interleukin 6 and 18 concentrations in albino mice following neonatal hypoxia ischemia insult," Pakistan Journal of Pharmaceutical Sciences, vol. 29, no. 5, pp. 1503-1508, 2016.

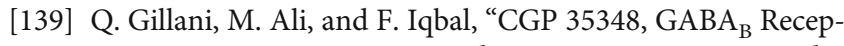
tor Antagonist, Has a Potential to Improve Neuromuscular Coordination and Spatial Learning in Albino Mouse following Neonatal Brain Damage," BioMed Research International, vol. 2014, Article ID 295215, 7 pages, 2014.

[140] H. Jiang, J. J. Lei, and Y. H. Zhang, "Protective effect of topiramate on hypoxic-ischemic brain injury in neonatal rat," Asian Pacific Journal of Tropical Medicine, vol. 7, no. 6, pp. 496-500, 2014.

[141] M. I. Vargas, J. Gariani, R. Sztajzel et al., "Spinal cord ischemia: practical imaging tips, pearls, and pitfalls," American Journal of Neuroradiology, vol. 36, no. 5, pp. 825-830, 2015.

[142] L. Wang, S. Li, Y. Liu et al., "Motor neuron degeneration following glycine-mediated excitotoxicity induces spastic paralysis after spinal cord ischemia/reperfusion injury in rabbit," American Journal of Translational Research, vol. 9, no. 7, pp. 3411-3421, 2017.

[143] A. L. Zhang, J. X. Hao, A. Seiger et al., "Decreased GABA immunoreactivity in spinal cord dorsal horn neurons after transient spinal cord ischemia in the rat," Brain Research, vol. 656, no. 1, pp. 187-190, 1994.

[144] Y. Kawasaki, T. Fujita, and E. Kumamoto, "Enhancement of the releases of GABA and glycine during ischemia in rat spinal dorsal horn," Biochemical and Biophysical Research Communications, vol. 316, no. 2, pp. 553-558, 2004.

[145] E. Durdag, Z. Yildirim, N. L. Unlu, A. Kale, and N. Ceviker, "Neuroprotective effects of vigabatrin on spinal cord ischemia-reperfusion injury," World Neurosurgery, vol. 120, pp. e33-e41, 2018.

[146] O. Kakinohana, M. P. Hefferan, S. Nakamura et al., "Development of GABA-sensitive spasticity and rigidity in rats after transient spinal cord ischemia: a qualitative and quantitative electrophysiological and histopathological study," Neuroscience, vol. 141, no. 3, pp. 1569-1583, 2006.

[147] T. Suzuki, Y. Okamoto, T. Sekikawa et al., "Effects of GABAergic drugs on the recovery of reflex potentials after 
spinal cord ischemia in cats," The Japanese Journal of Pharmacology, vol. 68, no. 4, pp. 423-429, 1995.

[148] C. Guo, F. Liang, W. Shah Masood, and X. Yan, "Hydrogen sulfide protected gastric epithelial cell from ischemia/reperfusion injury by Keap1 s-sulfhydration, MAPK dependent anti-apoptosis and NF- $\kappa \mathrm{B}$ dependent anti-inflammation pathway," European Journal of Pharmacology, vol. 725, no. 2, pp. 70-78, 2014.

[149] S. Gezginci-Oktayoglu, N. Orhan, and S. Bolkent, "Prostaglandin- $\mathrm{E}_{1}$ has a protective effect on renal ischemia/reperfusion-induced oxidative stress and inflammation mediated gastric damage in rats," International Immunopharmacology, vol. 36, no. 7, pp. 142-150, 2016.

[150] T. Brzozowski, P. C. Konturek, S. J. Konturek et al., "Role of prostaglandins generated by cyclooxygenase-1 and cyclooxygenase-2 in healing of ischemia-reperfusioninduced gastric lesions," European Journal of Pharmacology, vol. 385, no. 1, pp. 47-61, 1999.

[151] J. F. Zhang, Y. M. Zhang, C. D. Yan, and X. P. Zhou, "Neuroregulative mechanism of hypothalamic paraventricular nucleus on gastric ischemia-reperfusion injury in rats," Life Sciences, vol. 71, no. 13, pp. 1501-1510, 2002.

[152] Y.-M. Zhang, E.-Q. Wei, L. Li, W.-L. Qiao, L. Wang, and J.-F. Zhang, "Extracellular signal-regulated kinase pathways may mediate the protective effect of electrical stimulation of the paraventricular nucleus against ischaemia-reperfusion injury of the gastric mucosa," Clinical and Experimental Pharmacology and Physiology, vol. 34, no. 8, pp. 742-752, 2007.

[153] J.-Z. Zhu, S.-J. Fei, J.-F. Zhang et al., "Lateral hypothalamic area mediated the aggravated effect of microinjection of Baclofen into cerebellar fastigial nucleus on stress gastric mucosal damage in rats," Neuroscience Letters, vol. 509, no. 2, pp. 125-129, 2012.

[154] S. P. Zhu, S. J. Fei, J. F. Zhang et al., "Lateral hypothalamic area mediated the protective effects of microinjection of glutamate into interpositus nucleus on gastric ischemiareperfusion injury in rats," Neuroscience Letters, vol. 525, no. 1, pp. 39-43, 2012.

[155] D. S. Du, T. Zhu, S. T. Ren et al., " $\gamma$-aminobutyric acid-mediated neurotransmission in cerebellar-hypothalamic circuit attenuates gastric mucosal injury induced by ischemia-reperfusion," Neurogastroenterology and Motility, vol. 25, no. 4, p. 313, 2013.

[156] L. Gao, T. Zhu, G. Xie et al., "GABA ${ }_{A}$ receptor overexpression in the lateral hypothalamic area attenuates gastric ischemiareperfusion injury in rats," Molecular Medicine Reports, vol. 11, no. 2, pp. 1057-1062, 2015.

[157] L. Gao, H. Zhao, T. Zhu et al., "The regulatory effects of lateral hypothalamus area $\mathrm{GABA}_{\mathrm{B}}$ receptor on gastric ischemia-reperfusion injury in rats," Frontiers in Physiology, vol. 8, no. 9, p. 722, 2017.

[158] R. G. Khadaroo, T. A. Churchill, V. Tso, K. L. Madsen, C. Lukowski, and S. Y. Salim, "Metabolomic profiling to characterize acute intestinal ischemia/reperfusion injury," PloS One, vol. 12, no. 6, article e0179326, 2017.

[159] I. H. Mallick, W. Yang, M. C. Winslet, and A. M. Seifalian, "REVIEW: Ischemia-reperfusion injury of the intestine and protective strategies against injury," Digestive Diseases and Sciences, vol. 49, no. 9, pp. 1359-1377, 2004.

[160] C. A. Nankervis, P. J. Giannone, and K. M. Reber, “The neonatal intestinal vasculature: contributing factors to necrotiz- ing enterocolitis," Seminars in Perinatology, vol. 32, no. 2, pp. 83-91, 2008.

[161] M. Z. Schwartz, "Novel therapies for the management of short bowel syndrome in children," Pediatric Surgery International, vol. 29, no. 10, pp. 967-974, 2013.

[162] O. Corcos and A. Nuzzo, "Gastro-intestinal vascular emergencies," Best Practice \& Research. Clinical Gastroenterology, vol. 27, no. 5, pp. 709-725, 2013.

[163] P. Sastry, G. Hardman, A. Page et al., "Mesenteric ischaemia following cardiac surgery: the influence of intraoperative perfusion parameters," Interactive Cardiovascular and Thoracic Surgery, vol. 19, no. 3, pp. 419-424, 2014.

[164] J. H. Kim, J. Kim, J. Chun, C. Lee, J. P. Im, and J. S. Kim, “Role of iRhom 2 in intestinal ischemia-reperfusion-mediated acute lung injury,” Scientific Reports, vol. 8, no. 1, article 3797, 2018.

[165] J. Grootjans, K. Lenaerts, W. A. Buurman, C. H. C. Dejong, and J. P. M. Derikx, "Life and death at the mucosal-luminal interface: new perspectives on human intestinal ischemiareperfusion," World Journal of Gastroenterology, vol. 22, no. 9, pp. 2760-2770, 2016.

[166] A. Kubota, M. Kobayashi, S. Sarashina et al., "Gamma-aminobutyric acid (GABA) attenuates ischemia reperfusioninduced alterations in intestinal immunity," Biological \& Pharmaceutical Bulletin, vol. 41, no. 12, pp. 1874-1878, 2018.

[167] H. Li, J. Xiao, X. Li et al., "Low cerebral exposure cannot hinder the neuroprotective effects of Panax Notoginsenosides," Drug Metabolism and Disposition, vol. 46, no. 1, pp. 53-65, 2018.

[168] G. M. Chertow, E. Burdick, M. Honour, J. V. Bonventre, and D. W. Bates, "Acute kidney injury, mortality, length of stay, and costs in hospitalized patients," Journal of the American Society of Nephrology, vol. 16, no. 11, pp. 3365-3370, 2005.

[169] A. Kaddourah, R. K. Basu, S. M. Bagshaw, S. L. Goldstein, and AWARE Investigators, "Epidemiology of acute kidney injury in critically ill children and young adults," The New England Journal of Medicine, vol. 376, no. 1, pp. 11-20, 2017.

[170] M. Salvadori, G. Rosso, and E. Bertoni, "Update on ischemiareperfusion injury in kidney transplantation: pathogenesis and treatment," World Journal of Transplantation, vol. 5, no. 2, pp. 52-67, 2015.

[171] A. Kezic, N. Stajic, and F. Thaiss, "Innate immune response in kidney ischemia/reperfusion injury: potential target for therapy," Journal of Immunology Research, vol. 2017, Article ID 6305439, 10 pages, 2017.

[172] B. H. Ali, S. Al-Salam, M. Al Za'abi et al., "Renoprotective Effects of Gamma-Aminobutyric Acid on Cisplatin-induced Acute Renal Injury in Rats," Basic \& Clinical Pharmacology \& Toxicology, vol. 116, no. 1, pp. 62-68, 2015.

[173] L. A. Monasterolo, L. Trumper, and M. M. Elias, "Effects of gamma-aminobutyric acid agonists on the isolated perfused rat kidney," The Journal of Pharmacology and Experimental Therapeutics, vol. 279, no. 2, pp. 602-607, 1996.

[174] R. Brar, J. P. Singh, T. Kaur, S. Arora, and A. P. Singh, "Role of GABAergic activity of sodium valproate against ischemiareperfusion-induced acute kidney injury in rats," NaunynSchmiedeberg's Archives of Pharmacology, vol. 387, no. 2, pp. 143-151, 2014.

[175] S. Kobuchi, R. Tanaka, T. Shintani et al., "Mechanisms underlying the renoprotective effect of GABA against ischaemia/reperfusion-induced renal injury in rats," Clinical and 
Experimental Pharmacology \& Physiology, vol. 42, no. 3, pp. 278-286, 2015.

[176] M. Vafapour, M. Nematbakhsh, R. Monajemi et al., "Effect of $\Gamma$-aminobutyric acid on kidney injury induced by renal ischemia-reperfusion in male and female rats: genderrelated difference," Advanced Biomedical Research, vol. 4, no. 1, p. 158, 2015.

[177] N. Talebi, M. Nematbakhsh, R. Monajemi, S. Mazaheri, A. Talebi, and M. Vafapour, "The protective effect of $\gamma$ aminobutyric acid on kidney injury induced by renal ischemia-reperfusion in ovariectomized estradiol-treated rats," International Journal of Preventive Medicine, vol. 7, no. 1, p. 6, 2016.

[178] M. Cannistrà, M. Ruggiero, A. Zullo et al., "Hepatic ischemia reperfusion injury: a systematic review of literature and the role of current drugs and biomarkers," International Journal of Surgery, vol. 33, Supplement 1, pp. S57-S70, 2016.

[179] C. Huguet, A. Gavelli, and S. Bona, "Hepatic resection with ischemia of the liver exceeding one hour," Journal of the American College of Surgeons, vol. 178, no. 5, pp. 454-458, 1994.

[180] J. J. Lemasters and R. G. Thurman, "Reperfusion injury after liver preservation for transplantation," Annual Review of Pharmacology and Toxicology, vol. 37, no. 1, pp. 327-338, 1997.

[181] Y. I. Kim, "Ischemia-reperfusion injury of the human liver during hepatic resection," Journal of Hepato-BiliaryPancreatic Surgery, vol. 10, no. 3, pp. 195-199, 2003.

[182] M. von Heesen, S. Müller, U. Keppler et al., "Preconditioning by cilostazol protects against cold hepatic ischemiareperfusion injury," Annals of Transplantation, vol. 20, no. 3, pp. 160-168, 2015.

[183] H. Jaeschke, "Reperfusion injury after warm ischemia or cold storage of the liver: role of apoptotic cell death," Transplantation Proceedings, vol. 34, no. 7, pp. 2656-2658, 2002.

[184] K. Bavarsad, M. M. Riahi, S. Saadat, G. Barreto, S. L. Atkin, and A. Sahebkar, "Protective effects of curcumin against ischemia-reperfusion injury in the liver," Pharmacological Research, vol. 141, no. 3, pp. 53-62, 2019.

[185] W. Yang, J. Chen, Y. Meng, Z. Chen, and J. Yang, "Novel targets for treating ischemia-reperfusion injury in the liver," International Journal of Molecular Sciences, vol. 19, no. 5, article 1302, 2018.

[186] M. A. Silva, D. A. Richards, S. R. Bramhall, D. H. Adams, D. F. Mirza, and N. Murphy, "A study of the metabolites of ischemia-reperfusion injury and selected amino acids in the liver using microdialysis during transplantation," Transplantation, vol. 79, no. 7, pp. 828-835, 2005.

[187] T. Hori, L. B. Gardner, T. Hata et al., "Pretreatment of liver grafts in vivo by $\gamma$-aminobutyric acid receptor regulation reduces cold ischemia/warm reperfusion injury in rat," Annals of Transplantation, vol. 18, no. 6, pp. 299-313, 2013.

[188] T. Hori, L. B. Gardner, F. Chen et al., "Liver graft pretreated in vivo or ex vivo by $\gamma$-aminobutyric acid receptor regulation," The Journal of Surgical Research, vol. 182, no. 1, pp. 166-175, 2013.

[189] M. Yano, N. Adachi, K. Liu, and T. Arai, "Flumazenilinduced improvement of the central dopaminergic system in rats with acute hepatic failure," Journal of Neurosurgical Anesthesiology, vol. 17, no. 2, pp. 69-74, 2005.

[190] E. Sigel and A. Buhr, "The benzodiazepine binding site of $\mathrm{GABA}_{\mathrm{A}}$ receptors," Trends in Pharmacological Sciences, vol. 18, no. 11, pp. 425-429, 1997.
[191] T. A. Voronina, F. Z. Meerson, A. L. Mdzinarishvili, N. A. Abdikaliev, and M. G. Pshennikova, "Comparative evaluation of anticonvulsant and anti-arrhythmic effects of phenazepam, a benzodiazepine receptor agonist," Biulleten Eksperimental'noi Biologii I Meditsiny, vol. 109, no. 2, pp. 158-161, 1990.

[192] Q. Zhang and Z. Yao, "Flumazenil preconditions cardiomyocytes via oxygen radicals and $\mathrm{K}_{\mathrm{ATP}}$ channels," American Journal of Physiology-Heart and Circulatory Physiology, vol. 279, no. 4, pp. H1858-H1863, 2000.

[193] Z. Yao, B. C. McPherson, H. Liu et al., "Signal transduction of flumazenil-induced preconditioning in myocytes," American Journal of Physiology Heart and Circulatory Physiology, vol. 280, no. 3, pp. H1249-H1255, 2001.

[194] H. Y. Zhang, B. C. McPherson, H. Liu, T. S. Baman, P. Rock, and Z. Yao, " $\mathrm{H}_{2} \mathrm{O}_{2}$ opens mitochondrial $\mathrm{K}_{\text {ATP }}$ channels and inhibits GABA receptors via protein kinase C-E in cardiomyocytes," American Journal of Physiology. Heart and Circulatory Physiology, vol. 282, no. 4, pp. H1395-H1403, 2002.

[195] W. M. L. Neethling and A. J. Hodge, "The effect of diazepam on myocardial function and coronary vascular tone after endotoxemia in the isolated rat heart model," Inflammation Research, vol. 59, no. 11, pp. 907-913, 2010.

[196] M. N. Sharikabad, K. M. Ostbye, and O. Brors, "Increased $\left[\mathrm{Mg}^{2+}\right]_{\mathrm{o}}$ reduces $\mathrm{Ca}^{2+}$ influx and disruption of mitochondrial membrane potential during reoxygenation," American Journal of Physiology. Heart and Circulatory Physiology, vol. 281, no. 5, pp. H2113-H2123, 2001.

[197] L. M. Buja, "Myocardial ischemia and reperfusion injury," Cardiovascular Pathology, vol. 14, no. 4, pp. 170-175, 2005.

[198] G. A. Fishbeina, M. C. Fishbeina, and L. M. Buja, "Chapter 7 Myocardial Ischemia and Its Complications," in Cardiovascular Pathology, pp. 239-270, Academic Press, 2016.

[199] M. Neri, I. Riezzo, N. Pascale, C. Pomara, and E. Turillazzi, "Ischemia/reperfusion injury following acute myocardial infarction: a critical issue for clinicians and forensic pathologists," Mediators of Inflammation, vol. 2017, Article ID 7018393, 14 pages, 2017.

[200] Y. Q. Li, M. Takada, T. Kaneko, and N. Mizuno, "Distribution of GABAergic and glycinergic premotor neurons projecting to the facial and hypoglossal nuclei in the rat," The Journal of Comparative Neurology, vol. 378, no. 2, pp. 283294, 1997.

[201] F. Z. Meerson, E. V. Shabunina, L. M. Belkina, and M. G. Pshennikova, "Prevention of arrhythmias and cardiac fibrillation in acute ischemia and reperfusion by using a factor causing GABA accumulation in the brain," Kardiologiia, vol. 27, no. 5, pp. 87-89, 1987.

[202] H. Parsa, M. Faghihi, G. A. Kardar, and A. Imani, "Acute sleep deprivation induces cardioprotection against ischemia/ reperfusion injury through reducing inflammatory responses: the role of central GABA-A receptors," General Physiology and Biophysics, vol. 37, no. 3, pp. 345-352, 2018.

[203] H. Parsa, A. Imani, M. Faghihi et al., “Acute sleep deprivation preconditions the heart against ischemia/ reperfusion injury: the role of central GABA-A receptors," Iranian Journal of Basic Medical Sciences, vol. 20, no. 11, pp. 1232-1241, 2017.

[204] S. V. Nesterov, Y. A. Skorobogatova, A. A. Panteleeva et al., "NMDA and GABA receptor presence in rat heart mitochondria," Chemico-Biological Interactions, vol. 291, no. 8, pp. 4046, 2018. 


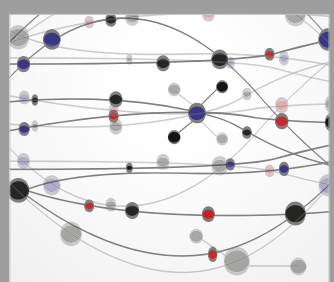

The Scientific World Journal
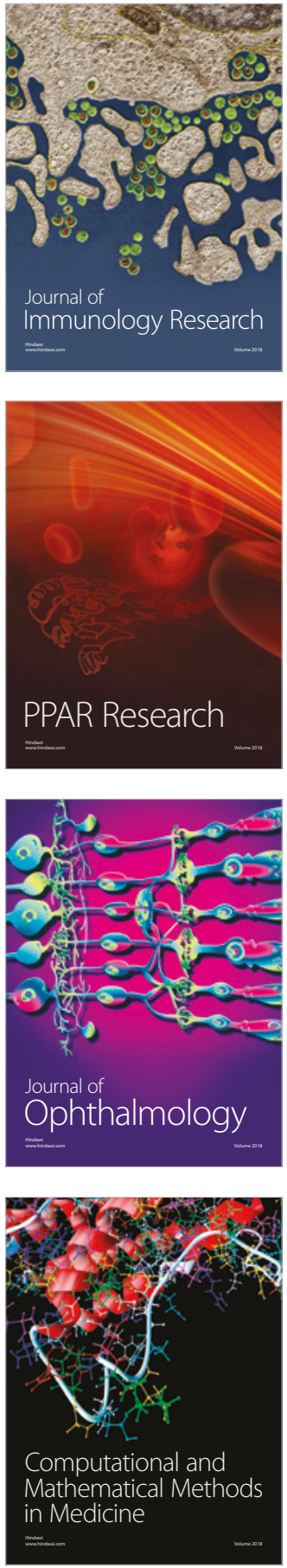

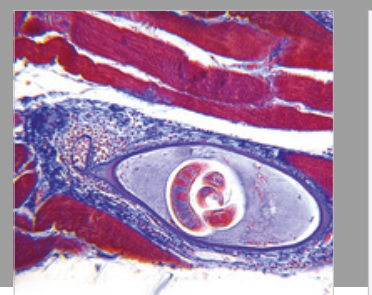

Gastroenterology Research and Practice

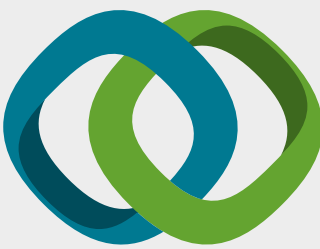

\section{Hindawi}

Submit your manuscripts at

www.hindawi.com
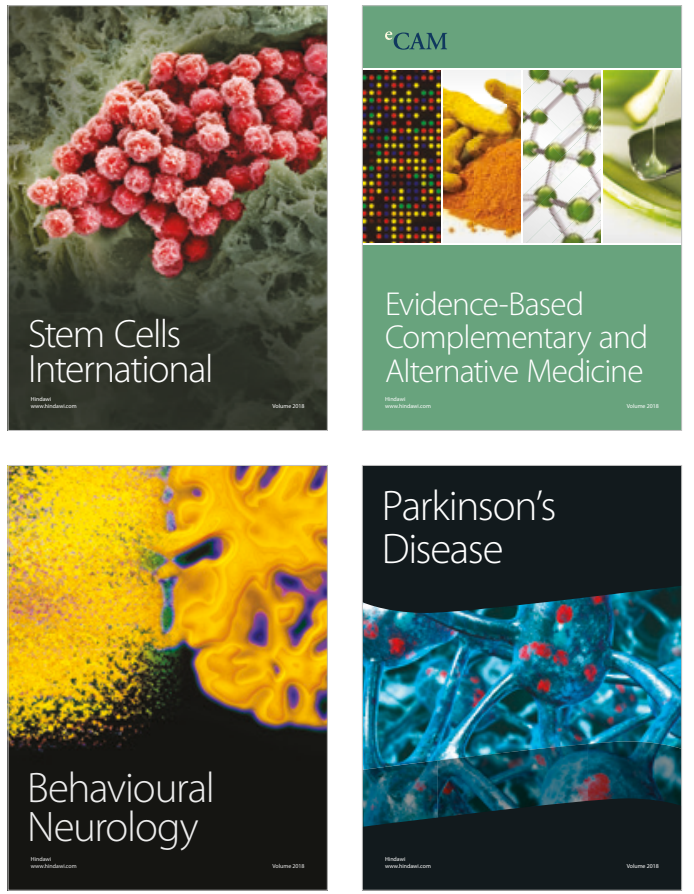

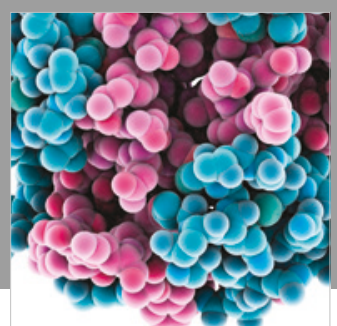

ournal of

Diabetes Research

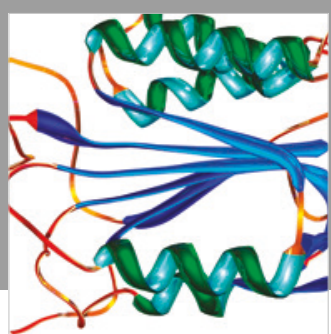

Disease Markers
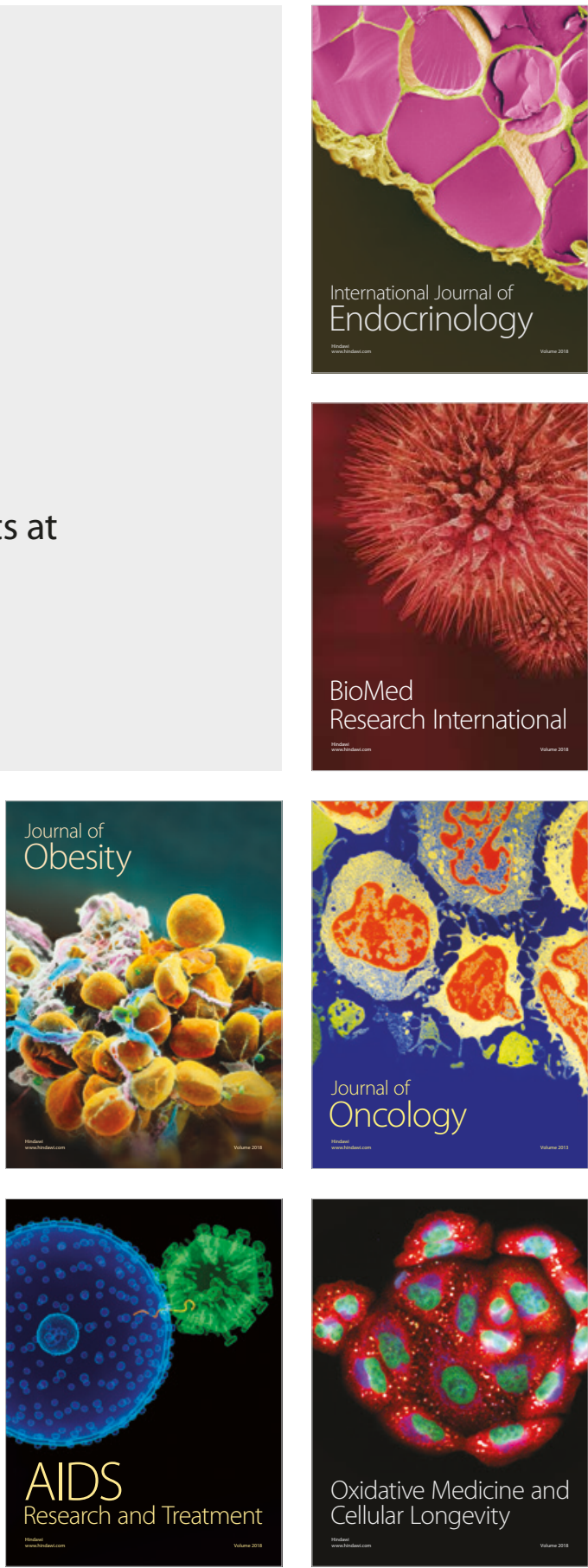